UNIVERSIDADE DE SÃO PAULO

FACULDADE DE ECONOMIA, ADMINISTRAÇÃO E CONTABILIDADE DEPARTAMENTO DE CONTABILIDADE E ATUÁRIA

PROGRAMA DE PÓS-GRADUAÇÃO EM CONTROLADORIA E CONTABILIDADE

ESTUDO DA DESTINAÇÃO DOS RECURSOS CAPTADOS EM OFERTAS

PÚBLICAS DE AÇÕES NO BRASIL E SEUS EFEITOS

George André Willrich Sales

Orientador: Prof. Dr. Iran Siqueira Lima

São Paulo

2012 
Prof. Dr. João Grandino Rodas

Reitor da Universidade de São Paulo

Prof. Dr. Reinaldo Guerreiro

Diretor da Faculdade de Economia, Administração e Contabilidade

Prof. Dr. Edgard Bruno Cornachione Junior

Chefe do Departamento de Contabilidade e Atuária

Prof. Dr. Luis Eduardo Afonso

Coordenador do Programa de Pós-Graduação em Contabilidade 


\section{ESTUDO DA DESTINAÇÃO DOS RECURSOS CAPTADOS EM OFERTAS PÚBLICAS DE AÇÕES NO BRASIL E SEUS EFEITOS}

Dissertação apresentada ao Programa de Pós-Graduação em Controladoria e Contabilidade da Faculdade de Economia, Administração e Contabilidade da Universidade de São Paulo, como requisito para a obtenção do título de Mestre em Ciências

Orientador: Prof. Dr. Iran Siqueira Lima

Versão Corrigida

(versão original disponível na Faculdade de Economia, Administração e Contabilidade)

\section{São Paulo}




\section{FICHA CARTOGRÁFICA}

Elaborada pela Seção de Processamento Técnico do SBD/FEA/USP

Sales, George André Willrich

Estudo da destinação dos recursos captados em ofertas públicas de ações no Brasil e seus efeitos / George André Willrich Sales. -São Paulo, 2012.

$89 \mathrm{p}$.

Dissertação (Mestrado) - Universidade de São Paulo, 2012.

Orientador: Iran Siqueira Lima.

1. Mercado de capitais 2. Captação de recursos financeiros 3. Investimentos 4. Ações I. Universidade de São Paulo. Faculdade de Economia, Administração e Contabilidade. II. Título.

CDD -332.041 
A minha esposa e filho, pelo apoio, amor e dedicação. 


\section{AGRADECIMENTOS}

A Deus, o Grande Arquiteto do Universo.

Ao Prof. Dr. Iran Siqueira Lima, pelo tempo destinado a orientação e todo apoio na orientação deste trabalho A humildade no tratamento dispendido comigo e com todos os profissionais que o cercam foi, certamente, o melhor aprendizado que pude obter neste período.

Ao Prof. Dr. Gerlando Augusto Sampaio Franco de Lima, pelas valiosas contribuições a esta dissertação, pelas aulas e conhecimento transmitido, pelo apoio, amizade e considerações.

Ao Prof. Dr. Héber Pessoa da Silveira, pelas críticas e sugestões oferecidas durante a qualificação, pelas aulas e conhecimento transmitido, e principalmente pelo exemplo de dedicação à docência e dicas acadêmicas.

Aos professores do departamento, pelo aprendizado nas disciplinas e pela convivência acadêmica: Ariovaldo dos Santos, Bruno Meirelles Salotti, Luis Eduardo Afonso, Nelson de Carvalho e Reinaldo Guerreiro.

Aos funcionários da FEA-USP, em especial a Maria Cristina Inácio, Rodolfo Ferrari e Evandro Figueiredo, por sua atenção e dedicação.

Aos amigos da pós-graduação, com quem dividi as alegrias e as amarguras deste período, pelo companheirismo, ajudas e troca de ideias, em especial para: Anderson Feitosa, Anderson F. Pinzan, Alex Mussoi, Alexandre Gonzalez, Ana Paula Capuano, Carlos Henrique da Silva Carmo, Azziz Beiruth, Carlos Eduardo Valeriano, Ivan Canan, em especial ao Rafael Sasso, Patrícia Oda e ao Eduardo Flores do programa da Fecap, pelas sugestões e críticas fundamentais para a melhoria deste trabalho, e pela ajuda com a coleta de dados.

Ao meu pai, Edison Sales e minha mãe, Lais Willrich Sales, pelo amor incondicional, carinho, incentivo e dedicação que talharam o meu caráter e me fizeram ser o que sou. À minha irmã Geórgia Willrich Sales e o meu irmão Edison Willrich Sales que sempre torceram e torcem pelo meu sucesso como pessoa e profissional.

E, finalmente, as pessoas mais especiais de minha vida, o meu filho Felipe Rodrigues Sales pelo seu amor simples e puro e a minha esposa Joyce Rodrigues Sales, que soube entender os sacrifícios, as ausências, os passeios negados, as fraldas não trocadas, as mamadeiras, banhos e colos não dados, entre outras pequenas grandes coisas. A dedicação e o amor de ambos tornaram a minha vida mais fácil neste conturbado período. Amo vocês com toda intensidade e serei eternamente grato. 
"Todas as coisas devem ser feitas da forma mais simples possível, porém não mais simples que o possível." Albert Einstein 


\section{RESUMO}

A pesquisa trata da relação entre a destinação dos recursos captados em oferta pública de distribuição de ações no Brasil e o retorno anormal no primeiro dia de negociação no pregão da bolsa. Teve como objetivo identificar se a destinação de recursos, como capital de giro, liquidação de passivos, aquisições, financiamento de clientes e investimentos em produção podem ser consideradas para tomada de decisão dos investidores, já que existe a obrigatoriedade legal da apresentação dessas informações. No período de janeiro de 2007 a dezembro de 2011 foram captados pelas empresas ofertantes, sendo que algumas mais de uma vez no período, o valor de R\$ 250,9 bilhões pelas subscrições de novas ações. O levantamento de dados considerou prioritariamente as informações apresentadas nos prospectos de ofertas públicas e nos comunicados de encerramento das ofertas, ambos registrados para acesso ao público em geral no site da Comissão de Valores Mobiliários (CVM) e, também, no site da BM\&FBovespa. Foram utilizadas duas hipótese distintas, uma relativa à destinação dos recursos e outra relativa ao grupo de investidores participantes da oferta, ambas confrontadas com o retorno anormal das ações no primeiro dia de negociações do pregão da BM\&FBovespa. Na tentativa de mensurar essas relações, adotou-se a analise de dados multivariada. Evidências apontadas pelos resultados sugerem que não há relações entre a destinação dos recursos e os retornos anormais para as companhias estudadas. No entanto, os resultados obtidos com a amostra referente ao grupo de investidores que são partes relacionadas com a administração da empresa, mostraram-se compatíveis com o retorno anormal das ações no primeiro dia de negociação na bolsa.

Palavras-chave: Captação. Investimentos. Mercado de Capitais. Ações 


\begin{abstract}
This research deals with the relation between the destination of the funds raised with the public offerings in Brazil and the abnormal return on the first trading day of the asset on the stock exchange. The main objective was to analyze if the funding destination, as working capital, settlement of liabilities, acquisitions, financing of customers, and investment in production would be considered by the investors, since there is regulatory obligation on the disclosure of such information. During the period from January 2007 until December 2011 the total funding raised on the public offerrings in the Brazilian stock market was $R \$ 250,9$ billion. The data collection process considered public offering prospects and other official papers registered on the Brazilian capital markets regulator - CVM, Comissão de Valores Mobiliários, website and also in the stock exchange (BM\&FBovespa) website. Two distinct hypotheses were used, one for the funding destination and another for the investors profile, were tested against the abnormal return on the first day of trading. Multivariate data analysis was used to analyze the data. The evidences suggest that there is no relationship between funding destination and abnormal returns for the selected sample, but the investors' relationship with the company's board members and abnormal returns seems to be relevant.
\end{abstract}

Keywords: Funding. Investments. Capital Market. Shares. 


\section{SUMÁRIO}

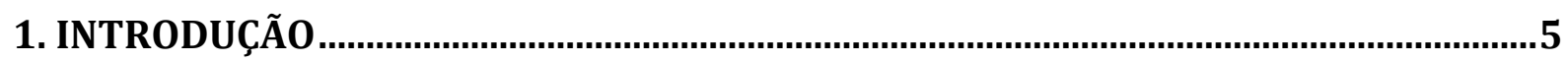

1.1. $O$ contexto da pesquisa ......................................................................................................5

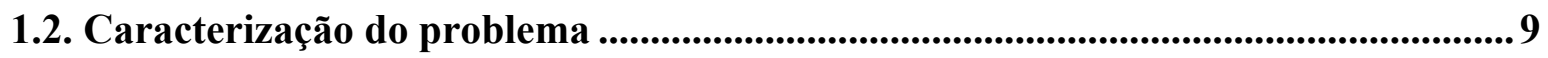

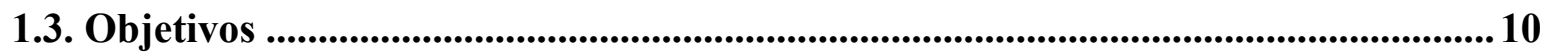

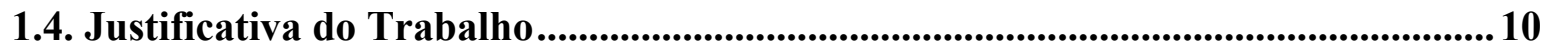

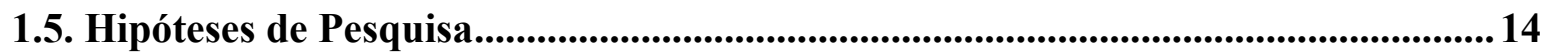

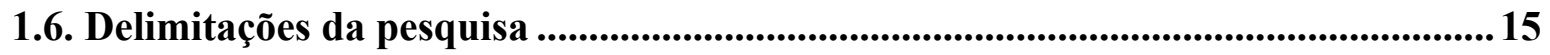

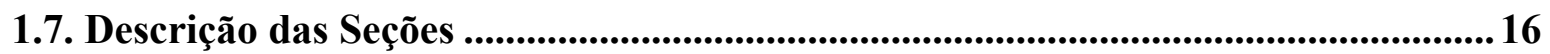

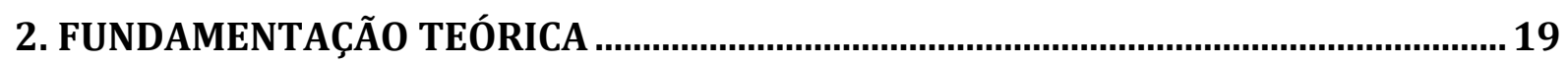

2.1. Formas de se acessar o mercado de capitais ......................................................... 19

2.2. Razões para Captação de Recursos ................................................................24

2.2.1. Teoria de Estrutura de Capital - Pecking Order Theory …........................................ 25

2.2.2. Teoria da Sinalização ................................................................................................................. 27

2.2.3. Teoria do Market Timing .............................................................................................................. 28

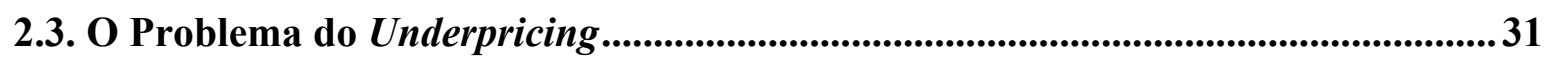

2.4. Teorias baseadas em assimetria de informação ....................................................... 32

2.5. Teoria dos Fractais ................................................................................................. 36

3. PROCEDIMENTOS METODOLÓGICOS..................................................................... 41

3.1. Classificação da pesquisa ............................................................................................................. 41

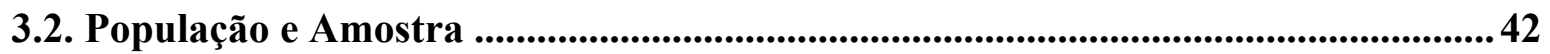

3.3. Definições teóricas e operacionais das variáveis.................................................42

3.3.1. Variável dependente: Retorno anormal no primeiro dia de negociação.................. 43

3.3.2. Variáveis independentes ............................................................................................ 44

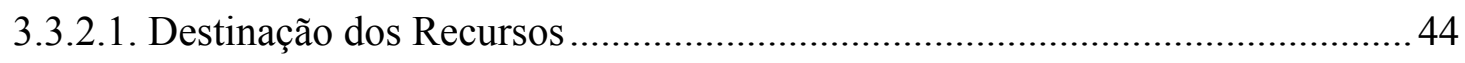

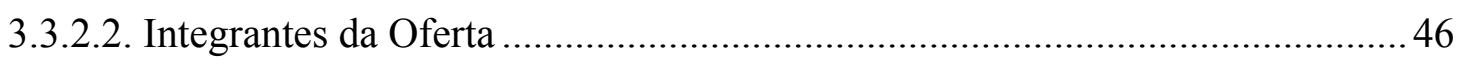

3.3.3. Variáveis de controle ......................................................................................................................5 50

3.3.3.1. Setor Econômico de Atuação ........................................................................... 50

3.3.3.2. Total de Ativos da Empresa ......................................................................... 51

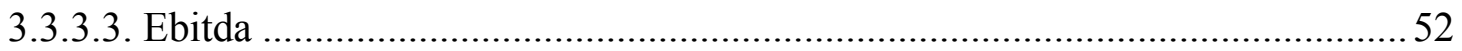

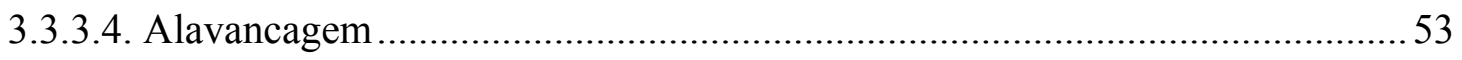

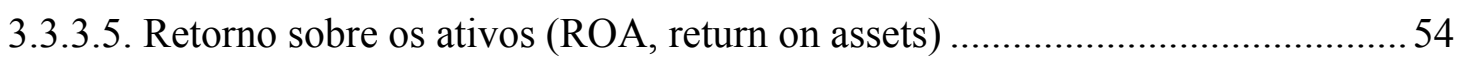




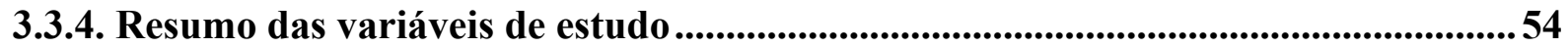

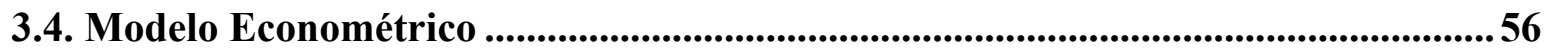

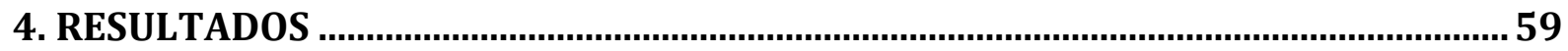

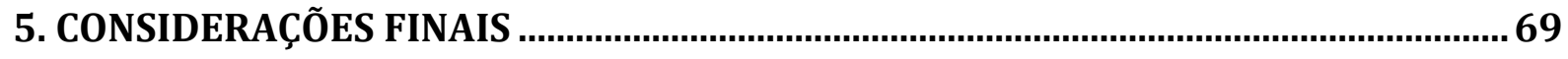

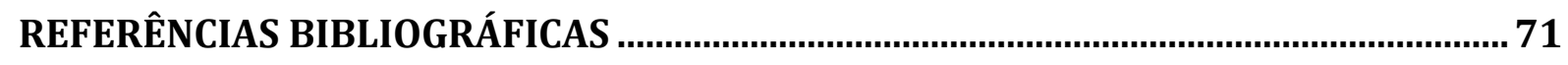

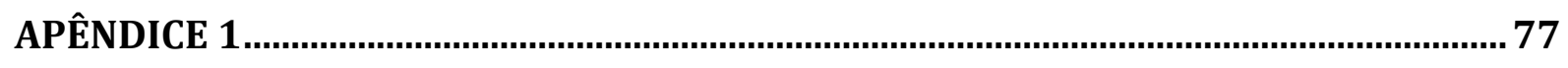

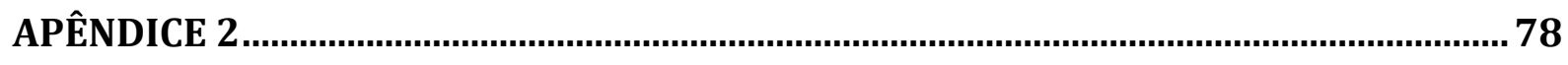

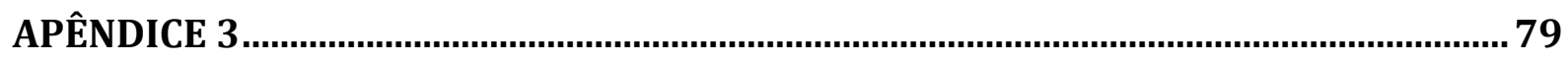




\section{LISTA DE TABELAS}

Tabela 1 - Ofertas primárias e secundárias, de 01/2007 a 12/2011 na BM\&FBovespa ..... 6

Tabela 2 - Resposta do Preço à informação contábil, Lopes e Martins (2007, p.7) .......... 35

Tabela 3 - Resumo das Posições em Relação à HME ....................................................... 36

Tabela 4 - Classificação da destinação de recursos ........................................................... 46

Tabela 5 - Classificação dos investidores participantes da oferta ...................................49

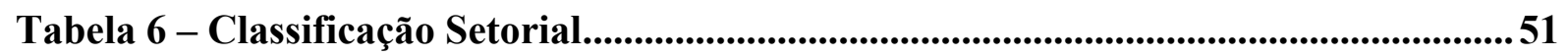

Tabela 7 - Quadro resumo das variáveis .................................................................55

Tabela 8 - Estatísticas descritivas do estudo ............................................................59

Tabela 9 - Outliers removidos da amostra .......................................................................6 60

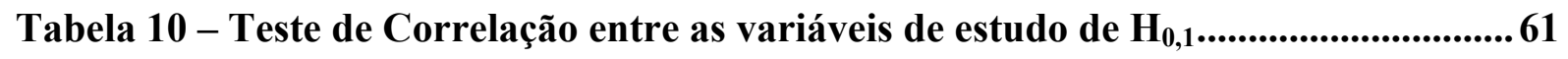

Tabela 11 - Modelo do estudo $H_{0,1}$ sem variáveis de controle .........................................62

Tabela 12 - Quantidade de Ofertas por Setor .............................................................6 63

Tabela 13 - Modelo do estudo $H_{0,1}$ com variáveis de controle ..........................................64

Tabela 14 - Modelo do estudo $\mathrm{H}_{0,2}$ sem variáveis de controle ............................................. 65

Tabela 15 - Relação de Participantes das Ofertas ...........................................................66

Tabela 16 - Modelo do estudo $\mathrm{H}_{0,2}$ com variáveis de controle .........................................6 67 


\section{LISTA DE FIGURAS}

FIGURA 1 - LINHA DO TEMPO PARA PRECIFICAÇÃO EM UNDERWRITING .............................. 7

Figura 2 - Lima ET AL. (2009, P.4) MERCADO DE CAPITAIS ............................................. 20

FIGURA 3 - ESPÉCIES DE OFERTAS PÚBLICAS, ELABORAÇÃo PRÓPRIA ............................... 22

FIGURA 4 - SEQUÊNCIA DE ACESSO AOS MERCADOS PRIMÁRIO E SECUNDÁRIO ...................... 22 


\section{INTRODUÇÃO}

\subsection{O contexto da pesquisa}

Durante a vida de uma empresa, poucos eventos financeiros são tão significativos quanto a emissão primária de ações que, independentemente de sua espécie (ordinária ou preferencial), permite: a entrada de novos sócios, a mudança de participação acionária, a elevação dos padrões de transparência e o aumento dos critérios de governança corporativa.

Nos eventos, anteriormente relacionados, estão descritas situações incidentais no que tange à destinação dos recursos captados, que, em suma, deveriam proporcionar uma maior capacidade de investimento das empresas. O ponto de estudo deste trabalho parte da destinação dada em prospecto de oferta pública de ações aos recursos captados de investidores, considerando a emissão primária de ações independentemente da espécie ser ordinária ou preferencial.

Nos últimos anos, de acordo com dados da BM\&FBovespa e da Comissão de Valores Mobiliários (CVM), o Brasil vivenciou um aumento expressivo no número de empresas que realizaram ofertas públicas de ações. Somente de janeiro de 2007 a dezembro de 2011 foram 154 ofertas, destinadas ao mercado primário (underwriting ${ }^{l}$ ) e/ou mercado secundário (block trade $^{2}$ ). O volume financeiro atingiu R\$ 313,5 bilhões $^{3}$ para o período, considerando, inclusive, a soma os valores de lotes suplementares (de até $15 \%{ }^{4}$ da oferta). Esse valor está distribuído em: R\$ 250,9 bilhões para underwriting e R \$ 62,5 bilhões para block trade.

\footnotetext{
${ }^{1}$ Segundo Cavalcante e Misumi (2002 p. 326) "É uma operação realizada por uma instituição financeira mediante a qual, sozinha ou organizada em consórcio, subscreve títulos de emissão por parte de uma empresa, para posterior revenda ao mercado". Usaremos o termo Underwriting por padronização com a literatura estrangeira.

2 Block Trade - de acordo com o site da BM\&FBovespa (2011) "Negócio ou leilão envolvendo um grande lote de ações em Bolsas de Valores e trata-se de operação de mercado secundário. Usaremos o termo Block Trade por padronização com a literatura estrangeira".

${ }^{3}$ Os números não sofreram qualquer ajuste inflacionário e dizem respeito aos valores descritos nos prospectos de encerramento das respectivas ofertas.

${ }^{4}$ A distribuição de lote suplementar está previsto no artigo 24 da ICVM 400, que diz: “...não poderá ultrapassar a 15\% da quantidade inicialmente ofertada".
} 
As análises das ofertas públicas de ações, realizadas no período, mostram que alguns setores da economia ${ }^{5}$ captaram mais recursos do que outros, conforme "tabela 1 ". Nota-se que para o setor de "Petróleo, Gás e Biocombustível" a captação foi de $42 \%$ com volume financeiro de R\$ 133,4 bilhões, desse valor, somente a empresa Petrobrás respondeu por mais de R\$120 bilhões. O setor "Financeiro e Outros" foi o mais equilibrado e captou mais de R\$73,4 bilhões, distribuídos entre 36 diferentes instituições.

\begin{tabular}{lcrr}
\hline \multicolumn{1}{c}{ SETOR ECONÔMICO } & EMPRESAS & VALOR DA OFERTA & \multicolumn{1}{c}{ PERCENTUAL } \\
\hline Bens Industriais & 5 & $\mathrm{R} \$ 3.485 .506 .782,60$ & $1,11 \%$ \\
Construção e Transporte & 39 & $\mathrm{R} \$ 26.023 .793 .235,75$ & $8,30 \%$ \\
Consumo Cíclico & 21 & $\mathrm{R} \$ 11.536 .801 .550,00$ & $3,68 \%$ \\
Consumo não Cíclico & 26 & $\mathrm{R} \$ 24.215 .202 .296,70$ & $7,72 \%$ \\
Financeiro e Outros & 36 & $\mathrm{R} \$ 73.433 .247 .904,25$ & $23,42 \%$ \\
Materiais Básicos & 11 & $\mathrm{R} \$ 32.946 .750 .462,99$ & $10,51 \%$ \\
Petróleo, Gás e Biocombustíveis & 6 & $\mathrm{R} \$ 133.406 .700 .894,30$ & $42,55 \%$ \\
Tecnologia da Informação & 2 & $\mathrm{R} \$ 981.196 .740,00$ & $0,31 \%$ \\
Telecomunicações & 2 & $\mathrm{R} \$ 2.798 .621 .964,80$ & $0,89 \%$ \\
Utilidade Pública & 6 & $\mathrm{R} \$ 4.680 .707 .191,02$ & $1,49 \%$ \\
TOTAL & $\mathbf{1 5 4}$ & $\mathbf{R} \$ \mathbf{3 1 3 . 5 0 8 . 5 2 9 . 0 2 2 , 4 1}$ & $\mathbf{1 0 0 , 0 0 \%}$ \\
\hline
\end{tabular}

Tabela 1 - Ofertas primárias e secundárias, de 01/2007 a 12/2011 na BM\&FBovespa. Fonte BM\&FBovespa

No mesmo período, algumas empresas realizaram ofertas públicas por mais de uma vez, por exemplo: a $\mathrm{Br}$ Malls $^{6}$ e PDG Realty ${ }^{7}$ captaram por 4 vezes, a Anhanguera Educacional ${ }^{8}$, Hypermarcas ${ }^{9}$ e Redecard $^{10}$ captaram por 3 vezes cada uma e diversas outras empresas realizaram ofertas por 2 vezes, vide "apêndice 1 ".

\footnotetext{
5 A nomenclatura de setores econômicos utilizada na Tabela 1 está de acordo com a definição dada pela BM\&FBovespa para segmentação das empresas.

${ }^{6}$ Companhia do Mercado de Shopping Centers sendo proprietária e prestadora de serviços (administração, consultoria, comercialização de lojas e Merchandising) considerada pela BM\&FBovespa como Setor Econômico "Financeiro e Outros"

${ }^{7}$ Companhia de investimentos com foco no mercado imobiliário considerada pela BM\&FBovespa como Setor Econômico "Construção e Transporte"

${ }^{8}$ Companhia privada com fins lucrativos do setor de ensino superior no Brasil como foco em nível superior considerada pela BM\&FBovespa como Setor Econômico "Diversos"

${ }^{9}$ Companhia que possui um Portfólio de marcas tradicionais com demanda estabelecida e potencial de crescimento considerada pela BM\&FBovespa como Setor Econômico "Consumo não Cíclico"

${ }^{10}$ Companhia da indústria de cartões de pagamento, credenciadora das bandeiras Mastercard e Diners no Brasil considerada pela BM\&FBovespa como Setor Econômico "Financeiro e Outros"
} 
Durante o processo de underwriting é emitido pela empresa ofertante, em conjunto com a instituição financeira coordenadora (underwriter ${ }^{l 1}$ ), o prospecto da oferta pública para que os investidores possam analisar todas as condições da colocação das ações e, assim, precificá-la. Essa análise torna-se mais relevante nos casos em que o preço da ação será definido em fase de bookbuilding, espécie de leilão comandado pelo underwriter.

Os autores Benveniste e Spindt (1989, p. 350), definem o bookbuilding como a prática que permite os coordenadores obterem informações dos investidores sobre o underwriting, Brealey et al. (2008 p. 888) retratam essa fase como o "método pelo qual os subscritores recolhem informações sobre a demanda que uma nova emissão terá no mercado". Portanto, é um processo em etapas, que respeita uma linha do tempo, ilustrado pela "figura 1".

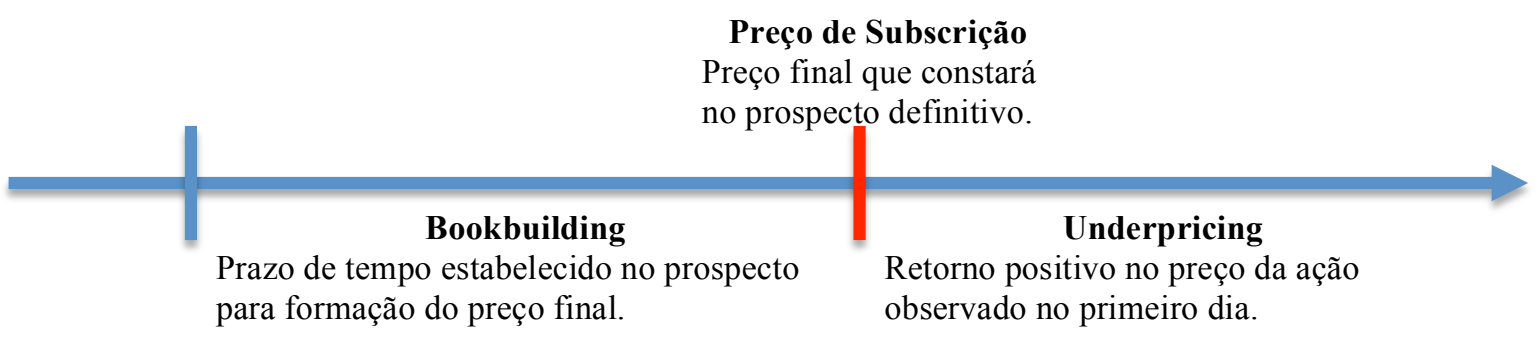

Figura 1 - Linha do tempo para precificação em Underwriting

O road show ${ }^{12}$ é uma importante prática para investigar os interesses dos potenciais investidores durante o bookbuilding. Caso, nesta fase, o interesse dos investidores pelas ações for alto, o preço atingirá o maior valor dentre faixa de preços sugeridas. Por outro lado, se for baixo o preço poderá atingir o menor patamar da faixa de preços.

Existem casos excepcionais em que a empresa ofertante, percebendo que os investidores não têm interesse ora desejado, cancela a oferta. Tal decisão não é simples de ser tomada, podendo acarretar efeitos negativos, pois numa futura investida da empresa o mercado se lembrará do ocorrido.

\footnotetext{
${ }^{11}$ Segundo Cavalcante e Misumi (2002 p.326) "Instituições financeiras especializadas em operações de lançamento de ações no mercado primário. No Brasil, tais instituições são, em geral, bancos de investimento, sociedades distribuidoras e sociedades corretoras que mantêm equipes formadas por analistas e técnicos capazes de orientar os empresários, indicando-lhes as condições e a melhor oportunidade para que a empresa abra seus capital ao público investidor, através de operações de lançamento." Usaremos o termo Underwriter por padronização com a literatura estrangeira.

12 Trata-se da apresentação da oferta pública pelo emissor e coordenador a potenciais investidores com o intuito de obter dados sobre interesse e demanda sobre os papéis.
} 
O processo de underwriting é realizado mediante contratação de agentes (com as mais diferenciadas obrigações) e de autorizações especiais de órgãos oficiais para emissão. Assim, parte dos recursos captados, também, destina-se à cobertura de custos, que podem ser relativos: (i) à preparação inicial de informações, que devem ser disponibilizadas nos prospectos; (ii) à contratação de underwriters que coordenam o lançamento dos papéis (iii) à campanha de marketing para divulgação do lançamento; (iv) à agência de rating ${ }^{13}$, que classifica os papéis; (v) à contratação de advogados para acompanhar e aconselhar em todo o processo e (vi) às taxas pagas aos órgãos como a CVM e a BM\&FBovespa.

A captação de recursos apresentada nos prospectos do período do estudo mostra a destinação dos recursos para: (i) a aquisição de concorrentes ou a incorporação de novos empreendimentos, visando um novo posicionamento estratégico da empresa em seu mercado de atuação ou em um novo; (ii) a modernização de seus produtos ou investimento na produção com vistas a atender a demanda e consequente aumento das receitas; (iii) o fornecimento de crédito ou aumento dos prazos de pagamento aos seus clientes de forma a aumentar as vendas; (iv) o pagamento de dívidas anteriores que proporcionem uma reestruturação do passivo pertencente a empresa, ou seja a troca do capital de terceiros com o capital próprio e (v) a utilização como capital de giro, ou seja, o recurso fornecido não possui uma destinação de longo prazo.

Assim, o tema dessa pesquisa envolve a discussão sobre a informação, apresentada nos prospectos, de destinação dos recursos captados (que, no período foi de R $\$ 250,9$ bilhões) serem relevantes para a formação do preço das ações a ponto de minimizar a variação do valor de fechamento no primeiro dia de negociações no pregão da bolsa de valores. Por outro lado, visa contribuir para fomentar acerca do tema de assimetria informal entre os investidores.

\footnotetext{
${ }^{13}$ Agência de Rating - de acordo com o site do Banco Central "Agências de Rating são instituições independentes especializadas na determinação e divulgação do risco das corporações, instituições financeiras e países (neste último caso, o chamado risco soberano). As principais empresas de rating no mundo são Moody's Investors Service, Standard \& Poor's, Fitch IBCA e Duff \& Phelps Credit Rating Co.”
} 


\subsection{Caracterização do problema}

Os investidores que participaram dos underwriting, durante a análise prévia do prospecto da oferta pública de ações, tiveram acesso a diversas informações, entre elas, a informação de destinação dos recursos. Contudo, em muitos casos, tais prospectos, que remontam centenas de páginas, não disponibilizam mais do que uma página para informar sobre a destinação dos recursos. Daí surge a dúvida sobre a relevância da informação como ponto de análise do investidor para avaliar o preço da ação no momento da colocação em bolsa.

O problema da assimetria informacional deveria ser mitigado com as informações prestadas pelo prospecto da oferta pública, como preconiza a ICVM 400 e suas atualizações $\operatorname{posteriores}^{14}$, o que não foi verificada no estudo de Saito e Maciel (2006). Especialmente, este trabalho visa medir se o item informacional de destinação dos recursos captados em underwriting impacta o resultado da captação de recursos.

As críticas direcionadas ao item destinação de recursos na normativa estão nos seguintes pontos: (i) omissão do grau de detalhamento de informações que o prospecto deve conter; (ii) como deve ser verificado a destinação dos recursos nos períodos subsequentes e (iii) falta de restrições de direitos, com caráter punitivo ao ofertante, pelo não cumprimento da destinação dos recursos indicada no prospecto. Contudo, a liberação da oferta, antes de ir a mercado, passa pela aprovação do prospecto na própria autarquia originadora da normativa, a CVM. Ao que tudo indica, a CVM analisa o prospecto e o cumprimento de todos os pontos exigidos pela normativa.

Do exposto, espera-se que esse trabalho possa contribuir para a discussão sobre a utilização das informações constante em prospecto de ofertas públicas, vis-à-vis à existência de evidências empíricas que corroboram e que negam a utilização das informações para precificação. Para tanto, a investigação tenta responder à seguinte questão de pesquisa: A existência da informação da destinação dos recursos em prospecto de oferta pública, de acordo com a sua alocação, afeta o preços das ações ofertadas em mercado primário?

\footnotetext{
${ }^{14}$ Instrução CVM N ${ }^{\circ} 400$, de 29 de dezembro de 2003, com as alterações introduzidas pelas ICVM No 429/06, 442/06, 472/08, 482/10, 488/10 e 507/11.
} 


\subsection{Objetivos}

O trabalho tem como objetivo central a análise empírica da destinação dos recursos financeiros declarado nos prospectos de underwriting das empresas no período de janeiro de 2007 à dezembro de 2011, incluindo o período da crise econômica global iniciada em 2008, em função da variação de preço das ações no primeiro dia de pregão. Descartamos deste estudo a análise dos block trade, pois estes não visam a entrada de capital para a empresa e constituem-se mercado secundário.

Os objetivos específicos são:

I - Verificar a existência de relação entre o uso da informação de destinação dos recursos e o desempenho das ações no primeiro dia de negociação no pregão; e

II- Verificar se existe relação de preferência por tipo de investidores em função da destinação dos recursos captados em oferta pública primária.

\subsection{Justificativa do Trabalho}

O presente trabalho poderá ajudar às empresas e, também, aos underwriters a avaliarem se o método empregado na formatação da destinação dos recursos captados no prospecto de oferta pública de ações surte efeito positivo ou negativo nos problemas de underpricing.

Quanto aos órgãos reguladores de mercado, a obrigatoriedade de divulgação ${ }^{15}$ da destinação do recursos dada na ICVM n ${ }^{\circ} 400$ e suas atualizações posteriores, poderá ser avaliada com o trabalho, ou seja, a percepção de que é necessário ser mais rigoroso ou mais brando com a descrição do item destinação de recursos nos prospectos de oferta pública.

Em relação aos investidores, a utilização de diversas informações para ajudar a achar um preço justo para um ativo do mercado de capitais é algo apreciado, contudo a informação

\footnotetext{
${ }^{15}$ A Lei das SA no art. 84 é omissa sobre a obrigatoriedade de informar a destinação dos recursos captados em oferta públicas, somente menciona no item "IV - a importância da entrada a ser realizada no ato da subscrição", a obrigatoriedade está na ICVM 400, que, no arcabouço legal, é hierarquicamente inferior.
} 
precisa ser relevante, completa e assertiva. Assim, o presente trabalho ajudará a avaliar se as informações de destinação de recursos são ou deveriam ser precificadas nas ações ofertadas ou se elas trazem apenas um fator especulativo que em nada contribui ao esforço final.

No que diz respeito apenas às empresas, é preciso saber se as informações muito detalhadas de divulgação das razões da estratégia de capitalização, indicando com primazia a destinação dos recursos, não se torna um fator de futuras perdas, já que a publicidade envolvida no prospecto permite a análise de concorrentes, fornecedores e especuladores. Nos prospectos de ofertas públicas analisados, dentre as centenas de páginas, observou-se a utilização de apenas 1 (uma) página para declarar a destinação de recursos.

Pela quantidade de informações obrigatórias e de caráter estratégico que uma empresa precisaria divulgar no prospecto, antes mesmo de ter os recursos em suas mãos, levaria a pensar que o prospecto não é o melhor instrumento para anunciar o que se pretende fazer. E, assim, pode haver aspectos negativos associados à divulgação detalhada da destinação de recursos.

Portanto, a amplitude de informações sobre a destinação dos recursos captados em um documento público pode ser relevante para os negócios da própria empresa medida que pode melhorar o preço da oferta. Como aspecto positivo, pode-se imaginar que o excesso de informação pode ajudar a empresa a evitar ou diminuir o underpricing $^{16}$

Contudo, o excesso de informações sobre a destinação dos recursos pode gerar efeitos negativos, pois, além de potenciais investidores, os concorrentes, fornecedores, credores e especuladores terão acesso as mesmas informações e, com isso, podem tomar algum proveito frente a empresa emissora, ocasionando eventuais perdas de performance futura.

Não há relatos de estudos brasileiros sobre as informações de destinação dos recursos captados serem capazes de ajudar na análise de precificação da emissão, ou seja, no momento do bookbuilding até a efetiva colocação da ação na bolsa.

\footnotetext{
${ }^{16}$ Underpricing é o retorno positivo da ação no primeiro dia de negociação, ou seja, o ativo foi emitido com preço inferior ao que poderia ter sido cobrado no bookbuilding, ou seja, é o "dinheiro deixado sobre a mesa" e quem fica com esse ganho é o investidor subscritor.
} 
Em que temos a formação do preço, existem estudos baseados nas expectativas dos investidores, denominado de ajuste parcial de preços (APP), que consiste na diferença entre o preço de emissão e o ponto médio da faixa de preços no prospecto preliminar. Assim, esperase que, quanto mais informações divulgadas melhor será para a precificação e, consequentemente, maior será o APP.

Autores como Loughran e Ritter (2002) estudaram o underpricing e desenvolveram um método para precificar ações denominado prospect theory model baseado no retorno e volatilidade considerando para os cálculos três semanas anteriores, levando-se em conta as informações públicas.

No passado, segundo Cavalcante et al. (2000 p. 41), as empresas brasileiras que realizaram IPO $^{17}$ (Initial Public Offering), nas décadas de 80 e 90, tinham o block trade como uma das principais formas de abertura de capital das empresas, ou seja, sem captação de recursos. Porém, no período analisado, tal evidência não foi o que observada em $94,57 \%$ das ofertas realizadas houve captação de recursos.

O "gráfico 1", também apresenta, detalhadamente as características da captação primária ou secundária, independentemente, do tipo da oferta ser resultante de um IPO ou SEO ${ }^{18}$.

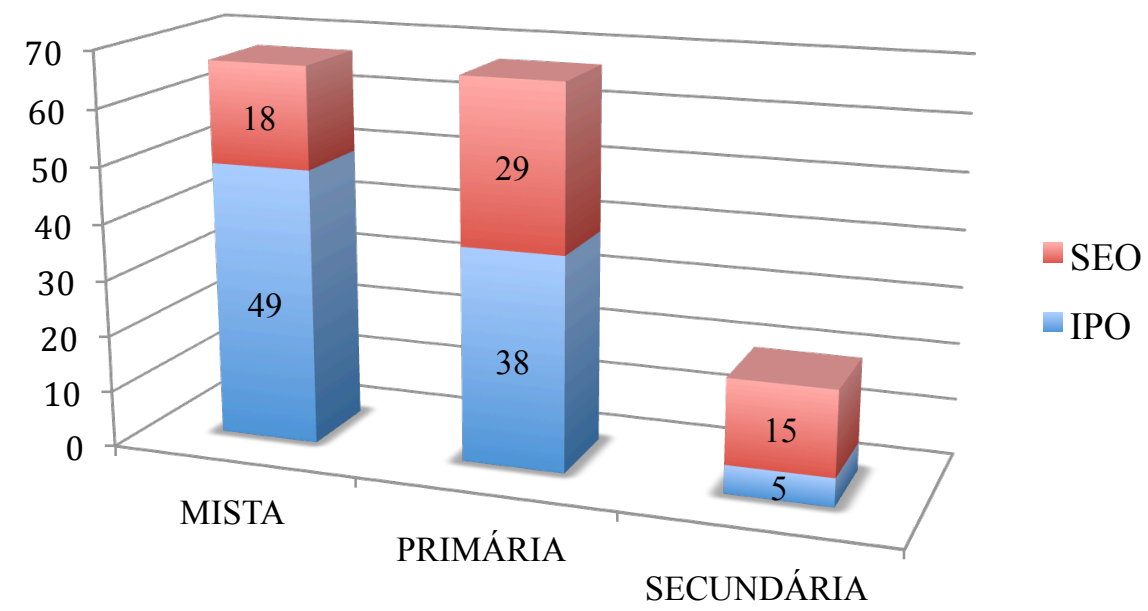

Gráfico 1 - Tipos de Ofertas realizadas entre Jan/2007 e Dez/2011 - Fonte BM\&FBovespa e CVM

17 Assaf Neto, (2005, p. 638) Primeira oferta de ações realizada por uma sociedade no mercado. Segundo o artigo 84 da lei n 6.404, "lei das S.A.", ao abrir o seu capital a empresa tem obrigação de apresentar prospecto contendo todas as informações referentes à oferta.

18 Seasoned Equity Offering (SEO) é um novo processo de oferta pública, que pode ser primário, secundário ou misto. 
A importância da destinação de recursos captados está em promover o desenvolvimento das empresas e, consequentemente, o crescimento socioeconômico do país (capital investido em busca de mais capital). Conforme apresentado por Cavalcante et al. (2000 p. 32), ...os valores destinados em oferta primária, nos mercados de capitais de países desenvolvidos representam um volume financeiro próximo ao do Produto Interno Bruto (PIB) de seus respectivos países.

No período de estudo deste trabalho o volume captado pelas empresas, com underwriting, no mercado brasileiro chegou à $\mathrm{R} \$ 250,9$ bilhões, conforme "gráfico 2".

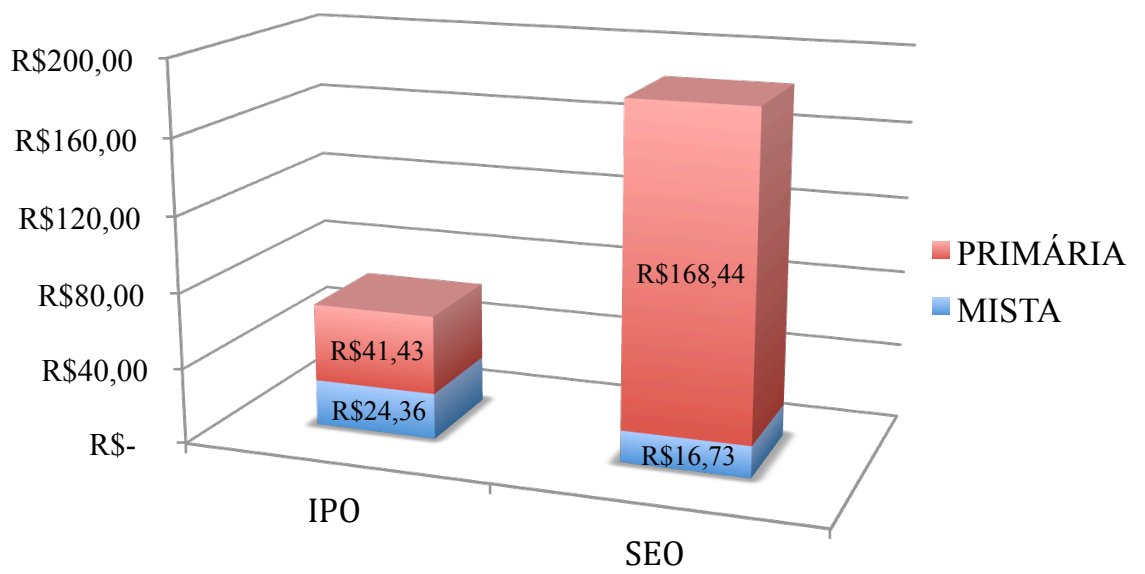

Gráfico 2 - Underwriting entre Jan/2007 e Dez/2011, valores em bilhões - Fonte BM\&FBovespa e CVM

A observação da destinação dos recursos captados em underwriting poderá mostrar um direcionamento sobre quais são as intenções das empresas ofertantes neste período de crise financeira global e de crescimento econômico. É importante relatar que, durante o período do estudo, o risco país do Brasil caiu consideravelmente, sendo declarado, pelas principais agências de rating internacionais como investiment grade ${ }^{19}$.

O resultado da análise, em estudos posteriores pode apontar se as empresas estão se beneficiando da liquidez existente para o mercado brasileiro no período devido a alguns

\footnotetext{
${ }^{19}$ Investment Grade - Dentro de uma escala formatada de riscos o termo, grau de investimento, faz parte das melhores faixas. As agências de rating Standard \& Poor's e Fitch Ratings elevaram o Brasil para essa condição em 2008 e a agência de rating Moody's elevou em 2009. De acordo com o Jornal Valor Econômico de 22/09/2011, "O rating foi elevado de Ba1 para Baa3, o primeiro dentro deste grupo de baixa risco pela escala da agência. A perspectiva para a nota é positiva. A empresa (Moody’s) agora se soma à Standard \& Poor's e à Fitch Ratings, que haviam elevado a nota brasileira para investment grade no primeiro semestre de 2008".
} 
aspectos como: (i) baixas taxas de juros internacionais e/ou (ii) pela diminuição da taxa básica do mercado financeiro interno (Taxa Selic).

Nesta linha de pensamento, estudos anteriores sugerem que baixas taxas de juros viabilizam os investimentos na produção (migração da poupança para o mercado de capitais) ao invés de promoverem (i) o mercado monetário (de emissão de títulos públicos federais pelo tesouro nacional) e (ii) o mercado de crédito (de intermediação financeira direta entre poupadores e empresas). No caso brasileiro, segundo Brito e Lima (2005) mostraram que empresas privadas tendem a se endividar mais que as empresas públicas ou estrangeiras.

Durante o processo de underwriting apresentam-se diversos custos que reduzem o total final da captação, porém diversos estudos apontam que o maior deles pode ser o underpricing. Para minimizar esse efeito e gerar um excesso na procura da oferta pública pelos investidores, a correta escolha do underwriter pode ter um papel fundamental.

Segundo Loughran e Ritter (2002) não há questionamentos dos gestores ao underwriter da oferta sobre o underpricing, pois assume-se, por parte de quem vendeu as ações, o reconhecimento do valor justo de mercado do papel. Além disso, os novos acionistas entrantes são justamente os mais beneficiados e não teriam motivação para questionar o underwriter.

Assim, pelo exposto, o presente trabalho também pode ser considerado como original na medida que pretende investigar se existe relação entre a destinação de recursos e o underpricing

\subsection{Hipóteses de Pesquisa}

Como os investidores utilizam-se das informações disponíveis para precificar as ações, sendo que deveria ser natural a avaliação da informação sobre a destinação dos recursos apresentado no prospecto inicial ajudar ou não a formar o preço da ação no bookbuilding. Uma boa descrição da destinação dos recursos ajuda a melhorar preço e diminuir os risco do underpricing. 
A destinação de recursos declarada no prospecto da oferta pública não se consuma só no momento do underwriting, também, é preciso avaliar a sua efetiva utilização ao longo do tempo. Tais informações devem, ou pelo menos deveriam, estar presentes nos relatórios financeiros subsequentes ao ato, mas não é objeto de estudo deste trabalho.

Visto o aspecto da divulgação da destinação dos recursos em underwriting. E, de acordo com pergunta apresentada no item 2 dessa seção, são propostas as seguintes hipóteses, apresentadas em sua forma nula, que devem ser comprovadas ou refutadas ao longo desse estudo:

$\mathrm{H}_{0,1}$ (hipótese nula 1): A existência da informação da destinação dos recursos em prospecto de oferta pública, de acordo com a sua alocação, afeta os preços das ações listadas em mercado primário no primeiro dia de negociação.

$\mathrm{H}_{0,2}$ (hipótese nula 2): Há relações intrínsecas entre os tipos de investidores com a variação do preço das ações ofertadas em mercado primário nas datas de suas colocações.

As suposições elaboradas para a pesquisa foram motivadas pela obrigatoriedade da divulgação das informações de destinação dos recursos captados em ofertas primárias, de acordo com a ICVM 400 e suas atualizações posteriores. Assim, este estudo objetiva saber se a informação é relevante para tomada de decisão dos investidores afetando o preço das ações no primeiro dia de negociação no pregão da bolsa, ou se haverá relevância no retorno em função dos tipos de investidores participantes da oferta.

\subsection{Delimitações da pesquisa}

A teoria de finanças possui diversos modelos para precificações de ações e mensuração de performance das empresas, o que permite diversas possibilidades de pesquisas com diferentes pontos de vista. Além das diversas teorias, existe a delimitação temporal, que para este trabalho está restrito ao período de janeiro de 2007 a dezembro de 2011. 
Outra delimitação da pesquisa está relacionada com a conjuntura econômica global e brasileira. No aspecto econômico global a crise do subprime oriunda do setor imobiliário, deflagrou uma grande volatilidade para o mercado de capitais. No aspecto econômico brasileiro o país obteve alguns avanços como o título de investment grade. Tais pontos não são considerados para avaliar os resultados finais obtidos.

A linha de estudo seguida foi o das teorias que buscam avaliar o underpricing como proposto por Ritter e Welch (2002), que identificaram o fenômeno em diversos países. A análise da qualidade informacional também foi considerado no trabalho, à medida que investiga quem foram os investidores que adquiriram as ações entre "informados" e "não informados". (ROCK; 1986).

Desse modo, a ênfase no trabalho está relacionada com a adaptação do modelo de Ritter e Welch (2002) para trabalhar com as informações constantes nos prospectos das ofertas públicas. Já a avaliação dos adquirentes das ações tem sua base informacional apresentada no comunicado de encerramento da oferta pública. Neste documento são identificados os adquirentes da oferta, bem como o montante de ações negociadas.

As demais delimitações estão descritas na seção 3 deste trabalho, que trata exclusivamente dos procedimentos metodológicos.

\subsection{Descrição das Seções}

Esta dissertação está organizada em cinco seções. A primeira seção trata dos aspectos contextuais da pesquisa, a identificação do problema e sua caracterização, dos objetivos e, também, da delimitação da pesquisa.

A próxima seção (segunda) trata dos aspectos teóricos que dão fundamentação e base à realização da pesquisa. A terceira seção retrata os procedimentos metodológicos adotados e o 
$\operatorname{corpus}^{20}$ analisado. A quarta seção relata as análises dos resultados encontrados e suas discussões.

E, por fim, na seção de considerações finais são apresentadas as limitações e sugestões de novas pesquisas, bem como, as conclusões.

${ }^{20} \mathrm{O}$ termo Corpus faz uso de uma abordagem empirista, contrária à abordagem racionalista tendo como ponto central o sistema probabilístico. (MARTINS; THEÓPHILO, 2007) 


\section{FUNDAMENTAÇÃO TEÓRICA}

Esta seção apresenta a análise procedida quanto aos principais aspectos teóricos deste estudo. Inicialmente, analisou-se as formas das empresas acessarem o mercado e o cumprimento legal da informação de destinação dos recursos. Logo após, realizou-se um aprofundamento acerca das razões que levam uma empresa a emitir ações. Em seguida buscou-se teorias de finanças capazes de justificarem a relevância das informações para precificação. E, finalizando com a exploração de modelos estatísticos empregados na detecção de práticas de gerenciamento de resultados.

A finalidade é fundamentar as escolhas metodológicas realizadas acerca da investigação proposta no objetivo geral, possibilitando a seleção do modelo e variáveis (seção 3), bem como auxiliar na análise dos resultados (seção 4).

\subsection{Formas de se acessar o mercado de capitais}

A poupança, definida como parte da renda não consumida por um indivíduo, que pode ser direcionada em forma de investimento quando existe a possibilidade de “... trocar um poder de consumo presente e certo por um poder de consumo futuro e incerto, se houver expectativa de que este será maior que o primeiro", Lima et al. (2009, p.1).

O mercado de capitais visa atender esses objetivos de médio e longo prazos, sendo composto por poupadores (investidores) e os tomadores (empresas) como principais atores e tendo as instituições financeiras não como contraparte financiadora, “....mas como interveniente que cobra uma comissão por facilitar a realização dos negócios”, Lima et al. (2009, p.4).

No mercado de capitais são negociados os valores mobiliários emitidos diretamente aos investidores por empresas de sociedade de capitais, tais como ações e debêntures. Por esta razão diz-se que o mercado de capitais permite a desintermediação financeira ligando diretamente os poupadores e os tomadores. A "figura 2" mostra a relação direta de financiamento dos investidores às empresas. 


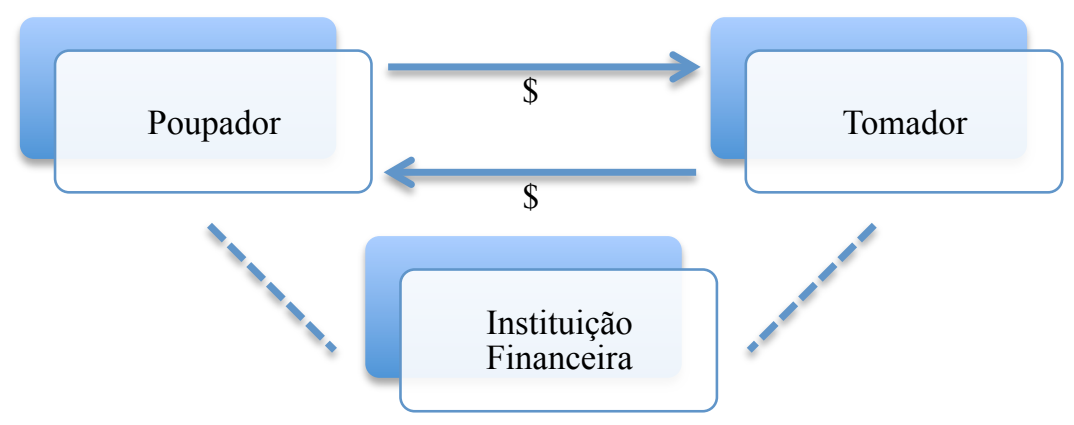

Figura 2 - Lima et al. (2009, p.4) Mercado de Capitais

A importância de se manter um mercado de capitais fortalecido é vital para o desenvolvimento econômico, Assaf Neto (2009) cita que a poupança gerada pelo mercado de capitais tem como destino desenvolver o comércio, indústria, serviços e, também, o próprio governo, pois, neste último caso, proporciona o ingresso de divisas de longo prazo na economia brasileira. Outros pesquisadores também chegaram à mesma conclusão sobre a correlação positiva entre crescimento econômico e desenvolvimento do mercado de capitais, Santos (2005, p. 198), diz que:

\footnotetext{
"A análise do processo de modernização dos mercados financeiros e de capitais no período de quarenta anos que se situa desde a criação do Banco Central do Brasil em 1964 até o final de 2004 evidencia, de forma clara, que existe uma correlação direta entre o desenvolvimento financeiro e crescimento econômico.
}

Pimentel (2007), também, obteve resultados que sugerem o crescimento econômico relacionado com investimento interno direto (capital fixo e poupança), tais resultados foram obtidos por meio do teste de causalidade de Granger. A importância dos recursos destinados ao mercado de capitais, segundo Cavalcante e Misumi (2002, p. 21), “permitem a circulação para custear o desenvolvimento econômico. Assim, uma empresa não precisará ficar restrita a sua geração de lucros (eventualmente insuficiente para suas necessidades)”.

As empresas podem acessar os investidores em mercado primário de três formas bem distintas, (i) por oferta pública, em que oferece suas ações à venda ao público em geral; (ii) por direito de subscrição, em que as novas ações são vendidas aos atuais acionistas; (iii) por colocação privada, em que a empresa vende seus valores mobiliários diretamente para um investidor ou grupo de investidores qualificados 
O foco deste trabalho está relacionado com a primeira forma descrita no item anteriormente relacionado. Quando uma empresa realiza uma oferta pública de distribuição abrindo seu capital, ao acesso de novos sócios, em mercados de acesso público (bolsa e balcão organizado) estamos tratado de um IPO. Nesse processo, o IPO pode ser de natureza primária (underwriting) ou secundária (block trade), sendo este oriundo de ações já emitidas e que não afetam o capital social e, consequentemente, o caixa da empresa.

Se a empresa necessitar de mais capital no futuro, poderá emitir (subscrever) e vender novas ações, em um novo processo de oferta pública subsequente chamado de SEO (Seasoned Equity Offering). Essa nova oferta funciona da mesma maneira que a primeira, porém não é mais chamada de IPO e, sim, apenas de underwriting, também conhecida como follow on. De acordo com site da BM\&FBovespa (2011) temos que:

\footnotetext{
“As ofertas públicas de ações (IPO e Follow on) podem ser primárias e/ou secundárias. Nas ofertas primárias, a empresa capta recursos novos para investimento e reestruturação de passivos, ou seja, ocorre efetivamente um aumento de capital da empresa. As ofertas secundárias, por sua vez, proporcionam liquidez aos empreendedores, que vendem parte de suas ações, num processo em que o capital da empresa permanece o mesmo, porém ocorre um aumento na base de sócios.”
}

Uma mesma oferta pública pode ser mista, ou seja, ser realizada no mercado primário (underwriting) e secundário (block trade) ao mesmo tempo, desde que devidamente informado no prospecto da oferta quem são os responsáveis, empresa e bloco vendedor.

A "figura 3" procura ilustrar as possibilidades de ofertas públicas previstas nas Instruções emitidas pela CVM, sendo que a ICVM 400 e suas alterações posteriores, regulamentam a distribuição pública e a ICVM 358 e suas alterações posteriores, regulamentam a aquisição de ações que envolvem o fechamento de capital e a troca de controle acionário com o tag along ${ }^{21}$.

Portanto, entende-se que uma oferta pública pode destinar-se a distribuição quanto a aquisição de ações.

\footnotetext{
${ }^{21}$ Segundo o artigo 254-A da Lei 6.404. A alienação, direta ou indireta, do controle da cia aberta se o adquirente realizar oferta pública de aquisição das ações ON pelo preço no mínimo de $80 \%$, esse percentual pode aumentar se a Cia fizer parte dos níveis de governança corporativa N2 (nível 2) e NM (Novo Mercado) da BM\&FBovespa.
} 


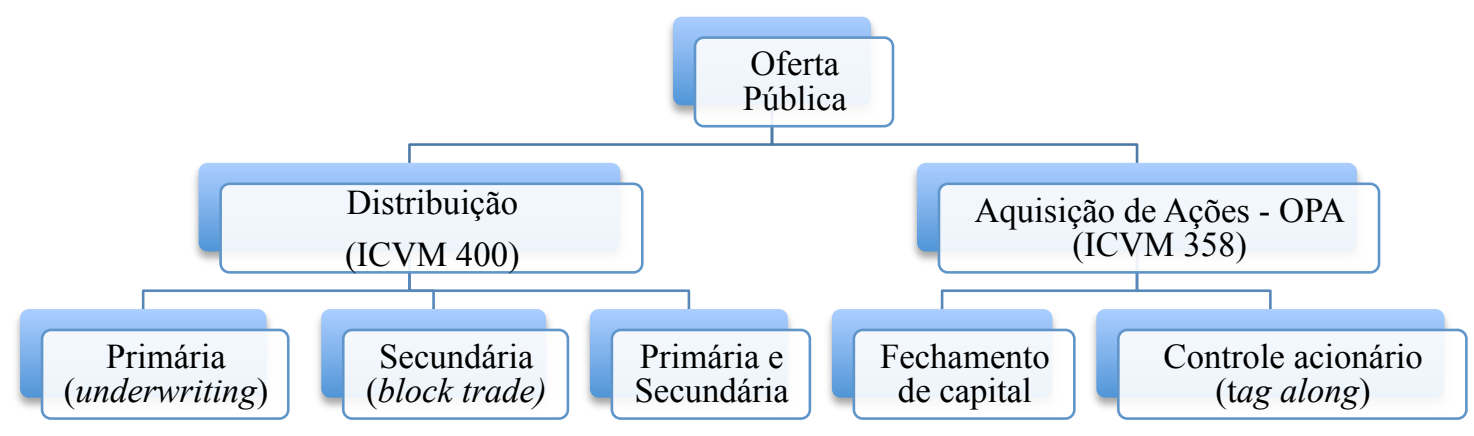

Figura 3 - Espécies de ofertas públicas, elaboração própria

Os agentes envolvidos no mercado de capitais e sua macro responsabilidades envolvidas na distribuição das ofertas públicas são apresentadas por Casagrande Neto et al. (2010) em um fluxo ilustrativo que permite acompanhar o processo numa ordem sequencial. Ver "figura 4".

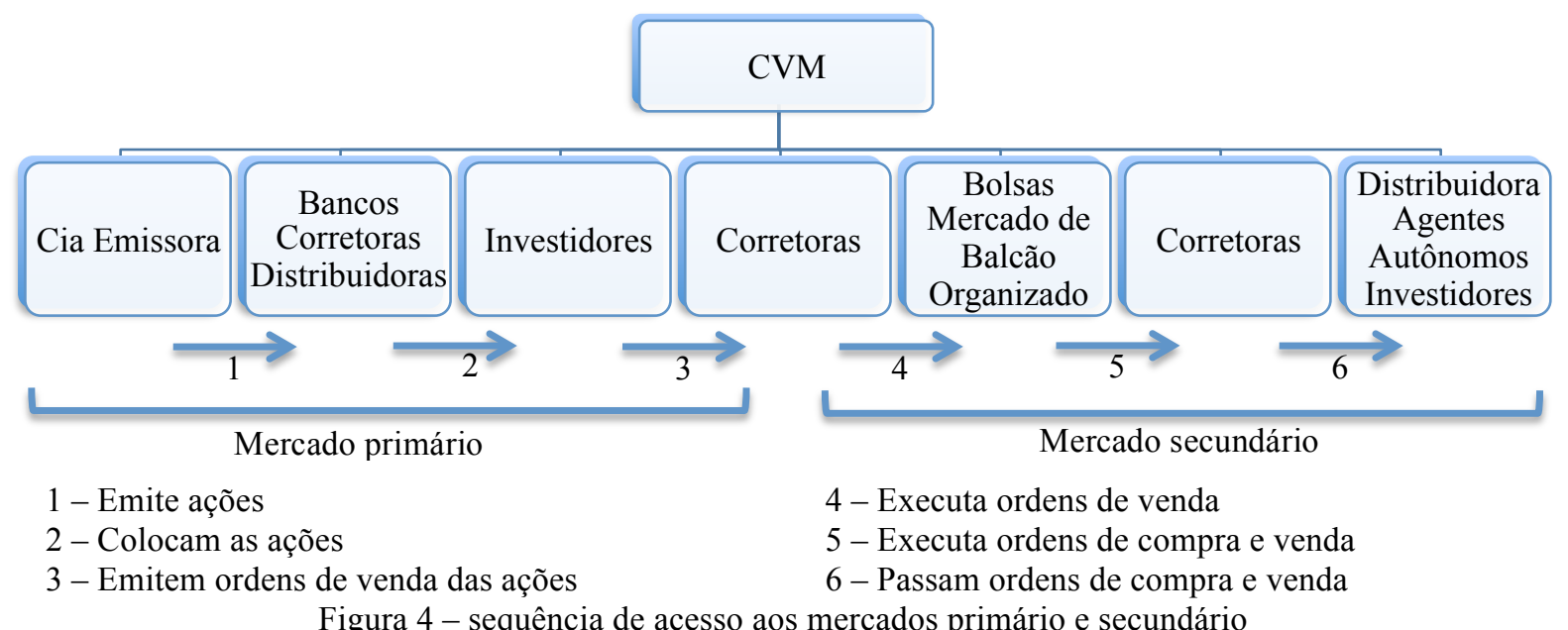

Figura 4 - sequência de acesso aos mercados primário e secundário

A ICVM n400 e suas atualizações posteriores, regulam as ofertas de distribuição de valores mobiliários no mercado brasileiro e tem como finalidade assegurar e proteger os interesses dos investidores e da poupança popular em geral, proporcionando que todos investidores tenham tratamento equitativo dos ativos ofertados, por meio de ampla, transparente e adequada divulgação de informações sobre a empresa e o que está sendo ofertado.

Baseado nesses princípios, a divulgação a ser apresentada em prospecto que deve conter informações de caráter obrigatório, como (i) Resumo contendo as características da operação (forma, quantidade, valores e prazo); (ii) a Identificação de administradores, consultores e auditores; (iii) Composição do Capital Social; (iv) Contrato de distribuição de valores mobiliários (a porcentagem em relação ao preço unitário de distribuição, a comissão de 
coordenação, a comissão de colocação, a comissão de garantia de subscrição; outras Comissões; o custo unitário de distribuição; as despesas decorrentes do registro; e outros custos relacionados); (v) Contrato de garantia de liquidez e de estabilização de preços; (vi) contrato de opção de colocação de lote suplementar; (vii) Estudo de viabilidade econômicofinanceira; (viii) Fatores de risco; (ix) situação financeira e suas análises pela administração; (x) Demonstrações financeiras do último exercício e descrição de propriedade, plantas e equipamentos; (xi) Estrutura organizacional (administração e funcionários); (xii) informações de contingências judiciais e administrativas; (xiii) Ata da assembleia geral extraordinária ou da reunião do conselho de administração que autorizou a emissão; (xiv) estatuto social atualizado da emissora; (xv) relatório da agência de rating. Para fins de nosso trabalho trataremos em especial à Destinação dos Recursos. Abaixo segue o artigo que trata da ICVM $\mathrm{n}^{\circ} 400$ e suas atualizações posteriores.

\footnotetext{
“Art. $30 \S^{\circ}$ O Prospecto deverá conter seção específica tratando da destinação dos recursos conforme a quantidade de valores mobiliários a ser distribuída ou o montante de recursos que se pretende captar, bem como a eventual fonte alternativa de recursos, caso seja admitida a distribuição ou a captação parcial."
}

O detalhamento informando como deverá ser feita a apresentação da Destinação dos Recursos no prospecto, encontra-se no anexo II da ICVM n400 e suas atualizações posteriores. São tratados todos os aspectos relativos a Documentos e informações Exigidos para o Registro, abaixo seguem a exigência legal:

“3.5 DESTINAÇÃO DE RECURSOS (somente aplicável à distribuição de valores mobiliários de emissão do próprio ofertante)

3.5.1 Exposição clara e objetiva do destino dos recursos provenientes da emissão, bem como seu impacto na situação patrimonial e nos resultados da emissora;

3.5.1.1 Se os recursos forem, direta ou indiretamente, utilizados na aquisição de ativos, à exceção daqueles adquiridos no curso regular dos negócios, descrever sumariamente esses ativos e seus custos. Se forem adquiridos de partes relacionadas, informar de quem serão comprados e como o custo será determinado;

3.5.1.2 Se os recursos forem utilizados para adquirir outros negócios, apresentar descrição sumária desses negócios e o estágio das aquisições. Se forem adquiridos de partes relacionadas, informar de quem serão comprados e como o custo será determinado; 
3.5.1.3 Se parte significativa dos recursos for utilizada para abater dívidas, descrever taxa de juros e prazo dessas dívidas e, para aquelas incorridas a partir do ano anterior, apresentar a destinação daqueles recursos, nos termos dos itens 3.5.1.1 e 3.5.1.2; e

3.5.1.4 No caso de apenas parte dos recursos ser obtida através da distribuição, quais outras formas de captação previstos para atingir seu objetivo. E na hipótese de serem vários objetivos e apenas parte dos recursos for obtida, quais objetivos serão prioritários. 3.5.2 Outras Fontes de Recursos - Se houver, discriminar outras fontes de recursos os quais terão destinação associada àquela relativa à distribuição pública; e

3.5.3 Fontes alternativas de captação, em caso de distribuição parcial.”

\subsection{Razões para Captação de Recursos}

A captação de recursos, via emissão pública, é um processo que altera consideravelmente a dinâmica de uma empresa, ainda mais se for pela primeira vez (IPO). Não existe nenhuma garantia de como o mercado avaliará a emissão pública. Contudo, existem fatores que podem direcionar essa avaliação como o histórico de lucratividade, crescimento, competitividade, corpo gerencial, continuidade dos negócios, entre outros menos objetivos.

A própria BM\&FBovespa disponibiliza em seu site a publicação "Por que abrir o capital", em que destaca as seguintes vantagens para o feito:

- Maior acesso de capital: para financiar projetos de investimento, pois projetos viáveis e rentáveis sempre atrairão investidores;

- Liquidez patrimonial: os atuais sócios podem dar liquidez as suas ações, pois ao abrir o capital é possível realizar parte do negócio em dinheiro no momento da abertura ou posteriormente;

- Ações como pagamento em aquisições: para atender a alternativa de crescimento com aquisições, sem descapitalizar a empresa adquirente, é possível realiza-las com o pagamento de suas próprias ações;

- Referencial de avaliação do negócio: a empresa aberta é constantemente avaliada pelos investidores, assim preço da ação reflete as expectativas futuras do negócio; e

- Melhora da imagem institucional: ao ser constantemente relacionada pela comunidade financeira, a empresa passa a ter mais projeção e reconhecimento com os diferentes públicos com que se relaciona. 
Nos prospectos de oferta pública foram encontradas as seguintes razões de destinação de recursos para a emissão de novas ações: (i) aquisição de concorrentes ou a incorporação de novos empreendimentos (ii) a modernização de produtos ou investimento na produção; (iii) fornecimento de crédito ou aumento dos prazos de pagamento aos seus clientes; (iv) pagamento de dívidas anteriores e (v) utilização como capital de giro.

\subsubsection{Teoria de Estrutura de Capital - Pecking Order Theory}

Diversos estudos referentes à estrutura de capital foram realizados a partir de Modigliani e Miller (1958), que concluíram inicialmente ser irrelevante a decisão da estrutura de capital para determinação do valor da empresa, pois em determinadas condições o valor das empresas alavancadas seria o mesmo da não alavancadas. Contudo ao avançarem os estudos sobre o tema, Modigliani e Miller (1963), admitem a possibilidade da combinação de financiamento ser benéfica para a valorização do valor da empresa.

Dessa forma, as empresas podem otimizar o custo do capital por meio de underwriting. Ross et al. (2008, p. 483) relatam que “...as empresas selecionam o quociente entre capital de terceiros e capital próprio que maximize seu valor ${ }^{22}$ ". Inclusive, sob esse prisma, Myers (1984, p. 23) testou empiricamente o conceito popular de teoria da hierarquia das fontes $^{23}$ que evidenciou uma ordem de preferência dos investidores.

Em outro estudo, Myers e Majluf (1984, p. 46) evidenciaram a existência de uma ordem de preferência para financiar empresas, aconselhando-as: “... deve emitir debêntures para ter capital externo, mas antes busque nas ações a retenção se for possível. Isto é, financiamento externo usando capital de terceiro é melhor do que financiamento por ações ${ }^{24 \text { "; }}$

Neste contexto, Myers e Majluf (1984) desenvolveram uma teoria para justificar as razões de financiamento de capital e a denominaram Pecking Order Theory. Com esse estudo,

\footnotetext{
22 firms select the debt-equity ratio at which firm value is maximized - Tradução livre

23 Pecking Order Theory

24 ...should go to bond markets for external capital, but raise equity by retention if possible. That is, external financing using debt is better than financing by equity - Tradução livre
} 
sugeriram que a assimetria informacional criava uma ordem para financiamento: primeiro os lucros retidos; segundo a dívida privada (empréstimos e financiamentos) e terceiro a emissão de dívida pública (debêntures) e ações.

Além da ordem de financiamento, segundo Kayo (2002), a relação entre capital de terceiros e capital próprio, também, afeta o risco financeiro de uma empresa, ou seja, quanto maior o financiamento com capital de terceiros maior é a alavancagem e, portanto, maior o risco financeiro.

Invariavelmente, os administradores, nos mercados desenvolvidos, primeiramente, buscam o autofinanciamento (fundos internos) por meio de retenção de lucros, Brealey et al. (2008, p. 315) evidenciaram esse fato para o mercado norte americano com empresas não financeiras, nos dados extraídos do Federal Reserve (banco central norte americano) no período de 1989 a 2003, onde apurou-se que os recursos oriundos de retenção de lucros são mais de três vezes superiores ao financiamento por instrumentos de dívida $\left(\mathrm{debt}^{25}\right)$, já a emissão líquida de ações foi negativa (recompra de ações) por todo o período, à exceção dos anos de 1992 e 1993.

Esse comportamento se repete em outros mercados desenvolvidos, Corbett e Jenkinsin (1997) avaliaram as empresas do Reino Unido, Japão e Alemanha, no período de 1970 a 1994 e constataram que mais de dois terços dos recursos advém de fundos internos. Referente à emissão de ações nos mercado de capitais do Reino Unido e Norte americano, Corbett e Jenkinsin (1997, p.17) sugerem "o interesse nos mecanismos de controle das empresas e para alcançar mudanças de controle em casos de angústia financeira"26.

Brau e Fawcett (2006, p. 39) pesquisaram junto a 336 CFOs (Chief Financial Officer ${ }^{27}$ ) as razões que levariam a empresa ao IPO e compararam a teoria com a prática. Segundo os pesquisadores as razões encontradas seguiram a seguinte ordem: (i) futuras aquisições; (ii) estabelecer um preço de mercado/valor da empresa; (iii) aproveitar a reputação da empresa; (iv) minimizar os custos de capital; (v) para aumentar a base de acionistas; (vi) reestruturação

\footnotetext{
${ }^{25}$ Dívidas oriundas de capital de terceiros, podem de natureza bancária (empréstimos e financiamentos) como natureza mobiliária (debêntures e notas promissárias)

${ }^{26}$ in the mechanisms for controlling companies and for achieving changes of control in cases of financial distress, Tradução livre

${ }^{27}$ Chefe do Setor Financeiro, principal executivo da área de financeira de uma empresa
} 
dos acionistas controladores; (vii) atrair a atenção de analistas; (viii) saída do capitalista de risco/realização; (ix) saída do fundo privado; (x) capital de terceiros muito caro.

Sob a ótica de Brau e Fawcett (2006) de que existe uma ordem de relevância, e devidamente adaptada às informações, dos prospectos de oferta pública. É possível comparar se há uma hierarquia de relevância sobre a destinação dos recursos, captados em underwriting, entre (i) Aquisições/Incorporações; (ii) Modernização/Produção; (iii) Crédito a Clientes; (iv) Liquidação de Passivo e (v) Capital de Giro, em função do underpricing.

\subsubsection{Teoria da Sinalização}

A teoria da sinalização visa à análise de situações em que as partes opostas, em negociações contratuais, estão interessadas em destacar, ou melhor, sinalizar algumas características, para minimizar o problema de assimetria informacional antes de se fechar a operação. Segundo Varian (2006), o investimento em sinais pode ajudar a resolver problemas causados pela informação assimétrica. Em suma, para Morris (1987, p. 48) a sinalização é um fenômeno geral aplicável em qualquer tipo de mercado.

Spence $(1973,1974)$, em seu trabalho pioneiro sobre sinalização, parte do pressuposto que o agente terá interesse em revelar sua informação privada, tornando-a pública, se ela trouxer maior utilidade. Obviamente, se houver custos para elaboração e divulgação da informação e a utilidade for suficiente para cobri-los, não haverá sinalização.

Outros pesquisadores fizeram uso da Teoria da Sinalização em Finanças, Dalmácio (2009), utilizou-a para medir a assertividade das previsões de mercado (analistas e investidores) em função da adoção das práticas diferenciadas de governança corporativa entre 2000 e 2008. Os resultados forneceram evidências positivas entre maior exigência da BM\&FBovespa para níveis de governança e maior acurácia das previsões do consenso dos analistas de investimento do mercado brasileiro

Sob a ótica da Teoria da Sinalização seria possível apontar se a qualidade da informação da destinação dos recursos captados, apresentada nos prospectos de oferta pública pelas 
empresas, influenciaria a tomada de decisão dos investidores. Contudo, nos prospectos de oferta pública das empresas objeto desse estudo, como dito anteriormente, apresentam o mínimo exigido pela normativa, o que dificultaria a comparação pela qualidade informacional.

\subsubsection{Teoria do Market Timing}

Outros trabalhos abordam diferentes motivações para realizar oferta de ações e entre elas encontram-se as condições favoráveis de mercado, a maior exposição em publicidade, a reestruturação societária, o desinvestimento, moeda corrente de troca e, finalmente, a estrutura média de capital das empresas no setor.

As condições do mercado apresentam a ideia de que as empresas escolhem o melhor momento de ir a público captar recursos. As empresas adiam suas ofertas caso seja percebida subvalorizarão de seus papéis, conforme a teoria do market timing (KORAJCZYK et al.,1991). De acordo com Ritter e Welch (2002, p. 27) “... as condições de mercado são o principal fator para oferta pública. O estágio da empresa, em seu ciclo de vida, parece ser o segundo fator mais importante ${ }^{28,}$.

Ainda sobre o trabalho de Ritter e Welch (2002), as motivações para abertura de capital, mais observadas, estão diretamente relacionadas com questões financeiras (i) para a empresa, com a obtenção de capital para financiar os projetos, e (ii) para os fundadores e outros acionistas, com o desenvolvimento da empresa no mercado de ações, para conversão de ganhos de capital (dinheiro) no futuro. No campo das motivações não financeiras o aumento da divulgação da companhia via mercado de capitais desempenha um papel secundário na tomada de decisão quanto à abertura de capital.

O trabalho de Pannemans (2002) apresentou como motivação de IPO o uso em projetos futuros ainda não identificados (portanto, suposições sobre o que fazer com os recursos captados) apenas pelas condições favoráveis de captação no mercado. Os pesquisadores Bradley, Jordan e Ritter (2003) estudaram as recomendações dos analistas de mercado e

28 ... that market conditions are the most important factor in the decision to go public. The stage of the firm in its life cycle seems to be the second important factor. - Tradução livre 
concluíram que existe viés positivo nas análises, o que pode influenciar no processo de underwriting.

Na linha de pensamento do Market Timing, se no período as ações de empresas do mesmo setor estão supervalorizadas, é natural que boas empresas realizem underwriting. Ritter (1991) tratou essa janela de oportunidades como market-to-book, pois o investidor vê esse movimento como um crescimento do setor, obrigando a empresa a ir em busca de capital para se financiar.

A maior exposição em publicidade é apontada por Maksimovic e Pichler (2001) que sugerem o aumento de publicidade e/ou reputação da empresa. Abrir o capital força o aprimoramento dos procedimentos de governança corporativa da empresa que acontece junto aos meios financeiros, clientes, fornecedores e junto aos próprios funcionários. A empresa torna-se mais visível, suas informações financeiras ganham mais credibilidade;

A reestruturação societária é a demanda do mercado de uma gestão familiar para uma gestão profissional, segundo Casagrande Neto et al. (2010, p. 41) “[...] processo sucessório, partilha de heranças e exclusão de sócios, podem ser solucionadas por meio da abertura de capital a novos sócios, o que também concorre para o desencadeamento da profissionalização".

O desinvestimento, através da oferta pública, permite ao proprietário realizar hoje resultados ainda não concretizados pela empresa. Em suma, beneficiando-se de parte de valorização dos fluxos de caixas futuros. A pesquisa de Zingales (1995) demonstrou que investidores internos vendem oportunamente ações em oferta pública para ganhos pessoais. Isso também ocorre com os venture capitalista ${ }^{29}$, que visam prioritariamente oportunidades para saírem da empresa com ganhos de capital.

As ações como moeda corrente de troca permitem o takeover $^{30}$, Zingales (1995) evidenciou que é muito mais fácil para uma empresa adquirir outra quando se é de capital aberto. Já Ritter e Welch (2002, p. 6), sob esse aspecto, concluíram ao analisar o mercado norte

\footnotetext{
${ }^{29}$ Venture Capital - Segundo Brealey et al. (2008 p. 888) "Capital de risco: Capital aplicado no financiamento de uma nova empresa".

${ }^{30}$ Takeover - Segundo o site da BM\&FBovespa (2011) "Processo de aquisição do controle societário de uma empresa por outro grupo, através da compra de ações da empresa. Pode ser amigável (quando há acordo prévio entre as partes) ou hostil"
} 
americano que, a venda de forma pública é muito mais vantajosa do que a venda direta. Embora não seja essa a razão principal das empresas abrirem o capital.

Algumas empresas, simplesmente, seguem a estrutura de capital média para o setor na qual estão inseridas, Ross et al. (2008, p. 482) são contundentes nesse aspecto, afirmando que:

\footnotetext{
"Embora isso possa parecer uma abordagem covarde, mas, pelo menos, faz com que as empresas não se afastem das práticas usuais. Afinal de contas, as empresas existentes em qualquer setor são as sobreviventes ${ }^{31 "}$.
}

Vimos que as razões de uma empresa ir ao público para levantar recursos no mercado de capitais são as mais diversas, contudo consideramos as seguintes citações: Modigliani e Miller (1958, p. 268) “... o valor de mercado de qualquer empresa é independente de sua estrutura de capital e é dado pela capitalização de seu retorno esperado à taxa apropriada à sua classe de risco"32 e de Ross et al. (2008, p. 438) que afirmam:

“[...] mercados de capitais perfeitos, com simetria total e completa de informações entre todos os participantes do mercado, o valor de mercado total dos valores mobiliários emitidos por uma empresa será determinado pelo poder de geração dos lucros futuros e pelo risco de seus ativos, sendo independente a mistura dos valores mobiliários emitidos para financiá-la estar entre instrumentos de dívida e ações ${ }^{33, "}$.

Essas duas últimas afirmações levaram o trabalho ao estudo da Hipótese de Mercado Eficiente $(\mathrm{EMH})$ como uma das razões à precificação de uma empresa por meio de ações abertas à negociação em mercados públicos (pregão de bolsa de valores).

\footnotetext{
${ }^{31}$ This may strike some as a cowardly approach, but it at least keeps firms from deviating far from accepted practice. After all, the existing firms in any industry are the survivors. Tradução Livre

32 the market value of any firm is independent of its capital structure and is given by capitalizing its expected return at the rate $\rho_{k}$ appropriate to its risk class - Tradução livre

33 perfect capital markets and with full and symmetric information among all market participants, the total market value of all the securities issued by a firm was governed by the earning power and risk of its underlying real assets and was independent of how the mix of securities issued to finance it was divided between debt instruments and equity capital. - Tradução livre
} 


\subsection{O Problema do Underpricing}

A captação de recursos por meio do underwriting pode gerar um desconto inicial para a empresa, denominado de underpricing (retorno positivo das ações no primeiro dia de negociação no pregão da bolsa). Diversos autores estudaram esse fenômeno, Loughran e Ritter (2002) verificaram no mercado norte americano, no período de 1970 a 1990 em uma amostra de 4753 empresas, um underpricing médio de 10\% positivo para os IPOs. Já Ritter (1991), para o período de 1975 a 1984, em uma amostra de 1526 IPOs, apurou uma média de retorno de $34,47 \%$.

Neste mesmo sentido, Ritter e Welch (2002, p. 1797) consolidaram os números de 1980 a 2001 e indicaram a captação de mais de US\$ 488 bilhões, com um underpricing superior a US\$ 106 bilhões. Ao dividirem a amostra em cortes temporais, encontraram o aumento do underpricing. Nos anos 80, a média de retorno para o primeiro dia de negociação foi de 7,4\%. No início dos anos 90 a média foi de $11,2 \%$ e ao final da década de 90 o valor cresceu para 18,1\%. Durante a bolha da internet, no período de 1999 a 2000, os underpricing chegaram, em média, a $65 \%$ e, no ano de 2001 , retornaram para $14 \%$.

Outros estudos focando o mercado de capitais europeu, também, apontaram a ocorrência constante para o underpricing em IPO, Keloharju (1993) analisou o mercado finlandês e observou 9,3\% de retorno no primeiro dia de negociações. Ljundqvist e Boehmer (2001) analisaram o mercado alemão e obtiveram 10,9\% de retorno no primeiro dia de negociações. No mercado Brasileiro, no período de 1980 a 1990, o resultado foi de 78,5\% em uma amostra de 62 empresas, de acordo com Aggarwal, Hernandez e Leal (1993).

O modelo de Rock (1986), testado por outros pesquisadores como Michaely e Shaw (1994) e Koh e Walter (1989), apresentou o underpricing como fruto da existência de investidores com vantagens informacionais. Desta forma, tais investidores não realizariam reservas quando os preços dos IPOs estivessem inflacionados e, em contra partida, realizariam pedidos quando os preços estivessem baixos. Por sua vez, os investidores que não possuem vantagens informacionais sentem-se desestimulados a participar do underwriting. Neste contexto, a empresa sente-se obrigada a embutir um prêmio nos preços das ações para que ambos 
investidores (com e sem vantagens informacionais) participem das reservas. Tal iniciativa gera um maior underpricing.

A adoção de mecanismos que produzissem mais informações de qualidade, poderia reduzir o problema da assimetria informacional e consequentemente o problema do underpricing. Partindo dessa ideia, os pesquisadores Saito e Maciel (2006) estudaram a adoção da ICVM 400 de 2003, no período de janeiro de 1999 a março de 2006 em uma amostra de 27 IPOs. O resultado mostrou um underpricing de $-0,4 \%$ para o período Pré-ICVM 400 (com 11 amostras) e de 10,4\% para o período Pós-ICVM400 (com 16 amostras). Aparentemente, a adoção da ICVM não mostrou-se relevante.

\subsection{Teorias baseadas em assimetria de informação}

As teorias de finanças baseadas em assimetria de informação são as mais utilizadas para explicar o retorno no primeiro dia de negociação. Tal situação surge do fato de algumas partes possuírem mais informações acerca da oferta do que outras, e o estímulo para a entrada de investidores menos informados estaria relacionado com a possibilidade de underpricing.

O estudo de Rock (1986) evidenciou a existência de dois tipos de investidores, os "informados" e os "não informados". O parâmetro informacional, que revela os dois tipos de investidores, refere-se ao conhecimento sobre os fluxos de caixa futuro da empresa colocadora.

Assim, no momento da colocação, como existe o rateio de ações entre todos os investidores participantes da oferta, é possível que investidores "não informados" adquiram ações que sejam do desejo dos investidores "informados". Dessa forma, os investidores informados, caso queiram as ações da empresa, devem enviar oferta ao pregão da bolsa, o que fará o valor das ações subir. Contudo se os investidores “informados” não desejarem as ações acontecerá a chamada "maldição do vencedor" 34 ".

\footnotetext{
${ }^{34}$ Quando os investidores "perdem ao ganhar" as ações colocadas a venda durante o processo de undewritting, ou seja, a quantidade de ações desejada pelo investidor é plenamente atendida na oferta e a partir do primeiro dia de negociações e, também, nos dias subsequentes o valor da ação adquirida cai.
} 
Para evitar a "maldição do vencedor" ou o underpricing é preciso precificar o preço da ação com acurácia. Essa importância não seria diferente para este trabalho, que busca medir a relevância da informação da destinação dos recursos capitados em underwriting versus o preço da ação.

Para as ações que já se encontram no mercado e, portanto, constantemente analisadas pelos investidores, existem diversas outras teorias para justificar os preços e até mesmo predizê-los. Contudo, o estatístico Maurice Kendall em $1953^{35}$ divulgou um trabalho intitulado: A análise econômica em séries temporais, no qual sugere que as variações dos preços são independentes uma das outras, tal quais os ganhos e as perdas em um jogo de dados. Dessa forma, pode-se concluir que preços passados não podem ser utilizados para definir preço futuro, pois se assim o fosse os investidores facilmente obteriam ganhos. (BREALEY; MAYERS; ALLEN, 2008).

Outros estudos apontam que as informações são essenciais para que os investidores possam previamente precificar valores mobiliários no mercado de capitais, tanto que diversos pesquisadores já trabalharam sobre o tema referente à Hipótese de Mercado Eficiente $\left(\mathrm{EMH}^{36}\right)$, que fora inicialmente sistematizada por Roberts (1967) e por Fama (1970). Os estudos desses pesquisadores apontaram que o valor de mercado de uma ação contém todas as informações disponíveis para precificá-la, ou seja, a volatilidade é gerada em grande parte, pela incerteza das informações disponíveis e, também, pela chegada de novas informações.

Segundo Fama (1976, p. 133) "Um mercado de capitais eficiente é aquele que é eficiente em

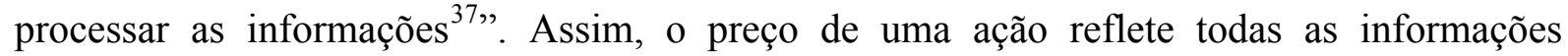
disponíveis trazendo implicações diretas para os investidores e para as empresas. Neste sentido, vejamos o que dizem Ross et al. (2008, p. 371):

\footnotetext{
“ - como a informação reflete os preços imediatamente, investidores devem apenas esperar obter retornos normais . Não há vantagem para o investidor o conhecimento da informação divulgada. $\mathrm{O}$ preço se ajusta antes do investidor negociar a ação.

- as empresas devem receber o valor justo pela venda de valores mobiliários, Justo significa que o preço que recebem pela emissão dos valores mobiliários é o valor presente. Portanto, as
}

\footnotetext{
35 M.G. Kendall, “The Analysis of Economics Time-Series, Part I. Prices” Journal of Royal Statistical Society 96 (1953) p. 11-25.

${ }^{36}$ A sigla EMH significa Efficient Markets Hytotesis, manteremos essa sigla por padronização com a literatura estrangeira.

${ }^{37}$ An efficient capital market is a market that is efficient in processing informations - Tradução Livre
} 
oportunidades de financiamento por meio de investidores tolos são inviáveis no mercado eficiente $^{38,}$.

Em suma, podemos entender que a transparência das informações deve ser o objetivo a ser perseguido pelos investidores e reguladores para a justa precificação dos ativos no mercado de capitais. Segundo Iudícibus e Lopes (2004, p. 70) “[...] a EMH proporcionou à Contabilidade a possibilidade de verificação do relacionamento dos números contábeis e das variáveis econômicas.".

E quais são essas informações? O que deve ser levado em conta para que possamos utilizar como fator de avaliação no mercado? Para responder essas perguntas Iudícibus e Lopes (2004, p. 75) apresentam: (i) que as informações $\Phi^{39}$ podem ser de qualquer natureza, obviamente que a contabilidade e a precificação de risco do ativo são de grande interesse para a teoria positiva da contabilidade ${ }^{40}$; (ii) correto seria apurar o lucro econômico após o desconto de todos os custos de transação (manutenção e negociação dos ativos) e, também, os de obtenção de informações, mas, por simplificação, consideram-se tais descontos como zero; e (iii) retornos anormais ao longo do período tendem a ser igual a zero, neste caso, diz-se que o lucro econômico é igual a zero.

Para que a EMH seja aceita é preciso apresentar as premissas básicas: (i) a expectativa de um participante do mercado é incapaz de influenciar sozinho os preços de negociação; (ii) os investidores são racionais, isto é buscam o maior retorno dados um nível de risco aceito; (iii) a disponibilidade e o custo das informações são desprezíveis (baixo) para todos os investidores; (iv) os créditos estão disponíveis a todos os participantes do mercado de forma que não há racionamento de capital; (v) não há restrição quanto ao acesso e divisibilidade dos valores mobiliários; e (vi) os participantes avaliam de forma similar o desempenho futuro do mercado. (ASSAF NETO, 2005)

\footnotetext{
${ }^{38}$...because information is reflected in prices immediately, investors should only expect to obtain a normal rate of return. Awareness of information when it is released does an investor no good. The price adjusts before the investor has time to trade on it. Firms should expect to receive fair value for securities that they sell. Fair means that the price they receive from issuing securities is the present value. Thus, valuable financing opportunities that arise from fooling investors are unavailable in eficient capital markets. Tradução Livre.

${ }^{39} \mathrm{Phi}$ (alfabeto grego maiúsculo) representa o símbolo para Conjunto de informações.

${ }^{40}$ Watts e Zimmerman (1986) relatam que a teoria positiva tem por objetivo explicar como a contabilidade se desenrola no mundo real, e predizer o que irá ocorrer (poder preditivo). Assim a teoria positiva da contabilidade explica as razões para determinada prática e prevê fenômenos contábeis que já existem, mas que ainda não foram observados pelos pesquisadores.
} 
Dentro desta eficiência de ajuste de preços, porém, deve ser considerada uma gradação em relação à qualidade, forma e tempestividade de divulgação das informações. Contudo para que a gradação seja aplicada é preciso investigar a relevância da informação, neste caso, às informações financeiras produzidas pela contabilidade, Lopes e Martins (2007, p.7) apresentam a “tabela 2" referente à resposta do preço à informação contábil:

\begin{tabular}{cll}
\hline $\begin{array}{c}\text { Eficiência do } \\
\text { Mercado }\end{array}$ & \multicolumn{1}{c}{ Mercado Eficiente } & \multicolumn{1}{c}{ Mercado não Eficiente } \\
\hline $\begin{array}{c}\text { Informação } \\
\text { Contábil }\end{array}$ & $\begin{array}{l}\text { A resposta é rápida e imediata. O } \\
\text { mercado é capaz de avaliar notas } \\
\text { explicativas e outras } \\
\text { evidenciações complexas } \\
\text { (derivativos, pensões etc.) }\end{array}$ & $\begin{array}{l}\text { A resposta não é rápida. Os } \\
\text { mercados não avaliam a } \\
\text { informação e não são capazes de } \\
\text { interpretar evidenciações mais } \\
\text { complexas. }\end{array}$ \\
Relevante & Sem reação & \multicolumn{1}{c}{ Inconsistente } \\
\hline
\end{tabular}

Tabela 2 - Resposta do Preço à informação contábil, Lopes e Martins (2007, p.7)

Analisando a tabela 2, podemos concluir que se a informação contábil for relevante afetará o preço das ações (considera-se a data da divulgação da informação para analisar as alterações nos preços), mesmo que não seja com o imediatismo do mercado eficiente (considera-se um prazo maior para analisar as alterações dos preços). Contudo quando a informação é irrelevante podemos desconsiderá-la em ambos os mercados, dada a não reação dos preços ou a sua inconsistência.

O mercado pode ser não eficiente quando pensamos que algumas das premissas apresentadas por Assaf Neto (2005, p. 209) não são verificadas na prática. Neste caso é constatado que: (i) não há homogeneidade na análise do resultado futuros do mercado em seus diversos instrumentos; (ii) na prática as informações, muitas vezes, não são disponibilizadas igualitariamente e/ou tempestivamente aos participantes do mercado; (iii) a racionalidade dos investidores nem sempre acontece, por diversas razões, (diferença de qualificação e conhecimento, efeito manada) afetando o resultado do mercado como um todo; ou ainda, por (iv) alterações governamentais como tributos e medidas restritivas.

Então, já que a realidade é diferente do mundo ideal dadas pelas premissas, haverá a necessidade de se graduar a EMH. Neste sentido podemos verificar a dissertação de Lima 
(2005, p. 58) apresenta a "tabela 3" com os resumos das posições de Fama em 1970 e 1991, à respeito desta gradação, com a indicação da antiga e da nova classificação.

\begin{tabular}{|c|c|c|}
\hline $\begin{array}{c}\text { Classificação } \\
\text { Antiga }\end{array}$ & Características & $\begin{array}{c}\text { Classificação } \\
\text { Nova }\end{array}$ \\
\hline Forma fraca & $\begin{array}{l}\text { O mercado incorpora completamente as } \\
\text { informações sobre os preços passados dos títulos. } \\
\text { Isto é, retornos anormais (acima da média de } \\
\text { mercado) não poderiam ser obtidos com base nas } \\
\text { expectativas de que os preços passados são bons } \\
\text { sinalizadores dos preços futuros. }\end{array}$ & $\begin{array}{l}\text { Previsibilidade de } \\
\text { Retornos } \\
\text { Passados }\end{array}$ \\
\hline Forma Semiforte & $\begin{array}{l}\text { Os preços refletem não apenas o histórico do } \\
\text { comportamento dos preços, como também toda } \\
\text { informação pública, tais como balanços das } \\
\text { companhias, notícias na imprensa, comunicados } \\
\text { de fatos relevantes, etc. }\end{array}$ & Estudos de Evento \\
\hline Forma forte & $\begin{array}{l}\text { Além das informações mencionadas anteriormente } \\
\text { (histórico dos preços e informações públicas), os } \\
\text { preços refletem as informações não públicas } \\
\text { (privadas). }\end{array}$ & $\begin{array}{l}\text { Testes de } \\
\text { Informação } \\
\text { Privada }\end{array}$ \\
\hline
\end{tabular}

Tabela 3 - Resumo das Posições em Relação à HME. Fonte: Lima (2005, p.58) adaptado de Fama (1970 e 1991)

\subsection{Teoria dos Fractais}

A HME, que leva em conta uma série de premissas vistas no item anterior, é duramente criticada por não conseguir explicar com clareza algumas variações de mercado. Neste caso, essas variações recebem o nome de anomalias ${ }^{41}$.

As anomalias são consideradas pela HME como uma forma de obtenção de ganhos no mercado acionário, e para justificar esse pensamento alguns pesquisadores isolaram alguns desses efeitos como:

- Tamanho das empresas: O estudo de Damodaran (1997) através da análise dos betas das empresas identificou que empresas pequenas, considerando valor de mercado e patrimônio líquido, obtêm maiores retornos do que empresas de maior porte. Para o

\footnotetext{
${ }^{41}$ Anomalias são fenômenos de retornos anormais que não podem ser explicados pelos tradicionais modelos de risco.
} 
mercado brasileiro Lopes e Galdi (2007) concluíram que a compra de ações winners ${ }^{42}$ por investidores renderiam $8,3 \%$ em um ano e $11,5 \%$ em dois anos, porém se selecionassem, do universo winners, empresas de pequeno e médio porte, respectivamente, o retorno anormal passaria para $34,5 \%$ e $98,2 \%$. O que contradiz a HME, pois ações de empresas pequenas tendem a ter menor liquidez de mercado, e altos custos de agência que afetam seus resultados.

- Período cíclico: Alguns estudos mostram anomalias nos meses de janeiro, como retornos mais altos do que os demais meses do ano. Outros estudos apontam anomalias negativas para as segundas-feiras em relação aos demais dias da semana.

- Índices preços sobre lucro: O estudo de Bodie et al. (2000) identificou que empresas com menores índices de preço/lucro, que em tese caracterizam-se pela estabilidade e/ou lento crescimento, obtiveram maior retorno do que empresas com índices maiores. Neste mesmo estudo sugere-se que a anomalia pode ser explicada pela possibilidade de recebimento de dividendos.

- Índices preço sobre o valor contábil: Alguns estudos apresentam que investidores utilizam como estratégia a busca de empresas com baixo índice de preços sobre o valor contábil, na esperança que estejam subavaliadas pelo mercado. Tal procedimento foi muito utilizado durante o período inicial da crise de 2008, inclusive com algumas indicações de analistas de mercado.

- Índices de liquidez: No estudo de Lopes e Galdi (2007) foram relatadas evidências para o mercado brasileiro que apontou a separação de empresas winners e losers funciona independentemente do nível de endividamento em que se encontram, ou seja, o retorno anormal não depende do índice dívida/ativo em que a empresa se encontra.

Como a HME é fortemente dependente da suposição de que os investidores tomam decisões a partir de um pensamento racional, o paradigma linear sobre a maneira como os investidores atuam sofreu duros questionamentos. Os estudos de Kahneman (2003) mostraram que investidores são propensos ao risco em função da probabilidade, pois entre escolher por uma

\footnotetext{
${ }^{42}$ Empresas com indicadores financeiros vencedores, segundo metodologia definida por Piotroski (2000).
} 
pequena perda certa e uma grande perda provável, os investidores escolhiam a grande perda provável, mesmo sabendo que as chances de êxito eram pequenas. Os mesmos investidores quando colocados em situação de ganho tinham comportamento inverso, preferiam o pequeno ganho certo e abriam mão do grande ganho provável.

Em suma, esse comportamento avaliado por Kahneman (2003) se afasta da hipótese de racionalidade, pois o investidor pode agir com excesso de confiança e, neste caso, desprezar informações relevantes, desde que estes não se ajustem ao cenário previamente escolhido.

Na mesma linha de pensamento, Peters (1991) avaliou em seus estudos que os investidores não reagem de forma linear em face de novas informações recebidas, pois muitas delas são momentaneamente ignoradas o que pode gerar reação tardia. Esse comportamento vai contra o paradigma baseado na Hipótese de Eficiência, sugerido por Fama, que visa um relacionamento linear de causa e efeito.

Um dos principais aspectos relacionado com esse comportamento, segundo Peters (1994), é a diferença de estratégia entre os investidores especuladores de curto prazo e os investidores de longo prazo. Cada grupo visa à liquidez, equilíbrio entre a oferta e a demanda, o que não tem nada a ver com o volume de negociações.

Sendo assim, os investidores que negociam no mercado possuem diferentes horizontes para seus investimentos e, portanto, fazem uso das informações disponibilizadas de forma distinta, o que proporciona diferentes visões acerca do que venha a ser o valor justo de uma ativo. Tal combinação de expectativas é que forma e viabiliza a liquidez existente no mercado.

De acordo com Peters (1994), a Hipótese dos Mercados Fractais ${ }^{43}$ é enfatizada pelo impacto do comportamento dos investidores em razão da liquidez e do horizonte dos investimentos e, dessa forma, a partir de observações empíricas, busca apresentar modelos que justifiquem o comportamento dos investidores e os movimentos de preços nos mercados. Assim, a ideia é buscar bases, dada a heterogeneidade do horizonte de investimento entre os investidores, nos

\footnotetext{
${ }^{43}$ De acordo com o dicionário Houaiss (2001) tem-se que: fractal é uma estrutura geométrica complexa cujas propriedades, em geral, se repetem em qualquer escala. Ou seja, um conjunto geométrico ou objeto natural cujas partes têm a mesma estrutura (irregular e fragmentada) que o todo, mas a escalas diferentes.
} 
princípios das finanças comportamentais que tratam da irracionalidade no momento da tomada de decisão.

Peters (1994) elaborou premissas para a HMF, são elas: (i) o mercado de capitais é composto de indivíduos com diferentes horizontes de investimento; (ii) a inserção de uma nova informação impacta de forma diferenciada os investidores com diferentes horizontes de investimento; (iii) a liquidez do mercado, estabilidade nas ofertas e demandas, ocorre quando os investidores (com diferentes horizontes) interagem entre si de forma ampla; (iv) os preços resultantes surgem a partir das estratégias de curto prazo (análise técnica) aliadas as estratégias de longo prazo (análise fundamentalista) e (v) nem todos os ativos possuem estratégia de longo prazo, neste caso foca-se nas análise de liquidez e de curto prazo. 


\section{PROCEDIMENTOS METODOLÓGICOS}

A metodologia utilizada para se alcançar os objetivos propostos em um trabalho científico é uma parte extremamente importante, como um caminho para se chegar a um determinado fim ou objetivo. De acordo com Martins e Theóphilo (2007) o método científico é um conjunto de regras para se observar fenômenos e inferir em conclusões.

Nesta seção os aspectos metodológicos utilizados para o desenvolvimento desta pesquisa são apresentados. Inclusive a forma de realização dos testes das hipóteses descritas na seção 1.

\subsection{Classificação da pesquisa}

Este estudo, do ramo das ciências factuais, baseia-se em objetos empíricos para teste experimental das hipóteses objetivando a redução da especulação excessiva das ciências sociais (MARTINS e THEÓPHILO, 2007). A sua classificação quanto ao método pode ser dada como exploratória, pois busca sintetizar conhecimentos específicos de uma área do saber. E, de fato, o caráter exploratório é justificado pela especificidade da pesquisa sobre a influência que a destinação dos recursos, dado em prospecto de oferta pública, poder afetar ou não o preço de colocação da ação.

Os meios utilizados para a operacionalização da pesquisa estão baseados em prospectos de oferta pública e outras informações, também, de caráter público, portanto, pode ser classificada como documentária. Neste sentido, vejamos o que dizem Martins e Theóphilo (2007, p. 55):

\footnotetext{
"A pesquisa documental tem semelhança com a pesquisa bibliográfica. A principal diferença entre elas decorre da natureza das fontes: a pesquisa bibliográfica utiliza fontes secundárias, isto é, materiais transcritos de publicações disponíveis na forma de livros, jornais, artigos etc. Por sua vez a pesquisa documental emprega fontes primárias, assim considerados os materiais compilados pelo próprio autor do trabalho, que ainda não foram objeto de análise ou que ainda podem ser reelaborados de acordo com o propósito da pesquisa."
} 


\subsection{População e Amostra}

Para responder a questão objeto desse trabalho, foram utilizadas empresas que ofertaram ações do período de janeiro de 2007 a dezembro de 2011, tendo como fonte primária de informação o site da BM\&FBovespa e, também, o site da CVM para coleta dos prospectos de oferta pública de ações. Empresas de capital aberto são obrigadas, for força legal, a disponibilizar as informações nessas instituições.

Neste período, observaram-se 154 colocações de ações por meio do instrumento de oferta pública, sendo que 132 colocações de ações, de 105 diferentes empresas, foram consideradas para o trabalho, pois realizaram a colocação de forma primária ou mista.

As informações sobre os preços finais das ofertas, bem como o total arrecadado com a oferta, foram extraídos dos comunicados ao mercado sobre o encerramento das ofertas. Tais informações também estão disponíveis, por força legal, nos sites das BM\&FBovespa e da CVM. Já os preços de fechamento do primeiro dia de negociação no pregão da BM\&FBovespa foram obtidos no banco de dados da Economática ${ }^{\circledR}$.

Os dados foram capturados, estudados e previamente tratados para que pudessem ser transferidos para os softwares estatísticos que foram utilizados para comparação dos modelos. Os softwares utilizados neste trabalho foram o R2, Stata ${ }^{\circledR}$ e Excel ${ }^{\circledR}$.

\subsection{Definições teóricas e operacionais das variáveis}

As definições teóricas, desde que inseridas em contextos específicos e sistematizadas, são de importante relevância para facilitar o compartilhamento do pensamento, remover ambiguidades e possibilitar a operacionalização prática. Assim, ao considerar que este estudo visa encontrar evidências de que as informações de destinação dos recursos afetam o preço das ações no primeiro dia de negociação, é de suma importância a apresentação de todas as variáveis utilizadas. 
Portanto, os próximos itens visam a apresentação das definições teóricas e operacionais das variáveis utilizadas nesta pesquisa.

\subsubsection{Variável dependente: Retorno anormal no primeiro dia de negociação}

Como variável dependente de estudo será utilizado o retorno anormal da ação de emissão primária e mista em seu primeiro dia de negociação no pregão da BM\&FBovespa. Para o cálculo do retorno anormal, de acordo com Ritter e Welch (2002), será utilizado o percentual de retorno da ação no primeiro dia (que é dado pelo preço observado do ativo ao fim do primeiro dia de negociação no pregão dividido pelo preço declarado no fechamento do prospecto de lançamento, menos 1) menos o retorno do índice Bovespa para o mesmo dia de negociação.

A fórmula abaixo traduz o retorno anormal.

$A R_{i, i p o}=\left[\left(\frac{p_{i, F, t}}{p_{i, O}}\right)-1\right]-R_{i b o v, t}$, onde:

$A R_{i, i p o}=$ Retorno anormal do ativo $i$ no IPO.

$p_{i, F, t}=$ preço observado do ativo $i$ no fim $F$ do dia do pregão $t$.

$p_{i, O}=$ preço observado no ativo $i$ no fechamento do prospecto $O$.

$R_{\text {ibov }, t}=$ Retorno do Ibovespa ibov para o primeiro dia de negociação $t$

O Índice Bovespa ${ }^{44}$ (Ibov) foi escolhido para representar a situação em que se apresentou o mercado durante o primeiro dia de negociação e, assim, isolar o efeito do mercado. O Índice Bovespa é um dos mais importantes indicadores de desempenho médio das cotações das ações líquidas na BM\&FBovespa que apura a valorização ou desvalorização dos principais

\footnotetext{
${ }^{44}$ IBov é uma carteira teórica que retrata as ações com $80 \%$ do volume negociado nos últimos 4 meses. Cada ação deve, no mínimo, ter mais de 12 meses de pregão e ser negociada em pelo menos $80 \%$ dos pregões. A apuração do IBov teve início em 2/01/1968 quando valia 100 pontos.
} 
papéis negociados no pregão e serve como indicador médio do comportamento do mercado acionário.

AR: Retorno Anormal (primeiro dia de negociação)

\subsubsection{Variáveis independentes}

\subsubsection{Destinação dos Recursos}

A destinação dos recursos utilizada para explicar $\mathrm{H}_{0,1}$ são informações obrigatórias nos prospectos de oferta pública que, invariavelmente, se apresentam na forma de percentuais em relação ao valor da captação primária.

Pelos estudos apontados, nas teorias relativas à estrutura de capital, o mercado tende a precificar as ações das empresas em razão da sua estrutura de passivo. A teoria da sinalização também poderia ajudar a explicar se a destinação apresentada como satisfatória ao mercado implicaria em um retorno anormal baixo ou nulo (MORRIS, 1987; VARIAN, 2006; DALMÁCIO, 2009).

Contudo outros estudos, como a teoria dos fractais, apontam que tal relação entre a precificação e as informações dadas ao mercado não se confirma na forma esperada, principalmente em momentos de grande oscilações, mas sim em função do comportamento dos investidores aliado ao horizonte de investimento (PETERS, 1991; PETERS, 1994; KAHNEMAN, 2003).

Portanto, para cada indicação de destinação, espera-se que os investidores tenham comportamentos distintos, conforme exposto a seguir:

- a liquidação do Passivo (Redução de Passivo) não deverá surtir efeito positivo junto aos investidores, pois tal informação sugere que a empresa encontra-se com dificuldade de financiamento por outros meios. Contudo, se a justificativa for a 
reestruturação do passivo, é possível que o comportamento dos investidores seja diferente;

- a captação para Caixa/Equivalente Caixa (Capital de Giro) não deverá surtir efeito positivo junto aos investidores, pois tal informação sugere que não há um casamento adequado entre as receitas e as dívidas de curto prazo;

- ao fornecimento de crédito (Clientes) poderá surtir efeito positivo junto ao aos investidores, pois tal informação sugere que se a empresa, em sua cadeia produtiva, é o elo financiador, apesar de existirem instrumentos de cessão de direitos creditórios capazes de financiar a empresa e, consequentemente, seus clientes. Contudo, se a empresa for uma instituição financeira, tal informação sugere dificuldade de captação de recursos com investidores por meio de instrumentos de renda fixa, sendo interpretada negativamente pelo mercado;

- a Modernização/Produção (Modernização e Recuperação Empresarial; Investimento em Infraestrutura, Cobertura de Custos Iniciais das Operações, Implantação de Projeto), poderá surtir efeitos positivos junto aos investidores, se a captação for para implementação de novos projetos e/ou cobertura de custos iniciais de implantação, tal informação sugere que a empresa poderá aumentar o seu lucro no futuro. Contudo, se o entendimento for de que a empresa deveria ter retido parte de seus lucros, ao longo de períodos anteriores, para amortizar os efeitos da depreciação e modernização, o resultado poderá ser negativo;

- a Aquisições/Incorporações (Reestruturação, Investimento em Imobilizado, Investimento ou Aquisição de Participações Societárias), deve surtir um efeito positivo, pois sugere um aumento estrutural e ganho de escala o que poderá melhorar o lucro por ação.

A "tabela 4" a seguir, apresenta a codificação utilizada neste trabalho para identificar os diferentes tipos de destinação de recursos. 


\begin{tabular}{|c|c|}
\hline Código & Destinação dos Recursos \\
\hline GIR & $\begin{array}{l}\text { Percentual destinado para Caixa ou Equivalentes } \\
\text { Caixa (Capital de Giro) }\end{array}$ \\
\hline PAS & Liquidação do Passivo (Redução de Passivo \\
\hline FIN & Fornecimento de Crédito a clientes (Financiamento) \\
\hline PRD & $\begin{array}{l}\text { Modernização/Produção } \text { (Modernização e e } \\
\text { Recuperação Empresarial; Investimento em Infra- } \\
\text { Estrutura, Cobertura de Custos Iniciais das } \\
\text { Operações, Implantação de Projeto) }\end{array}$ \\
\hline $\mathbf{A Q U}$ & $\begin{array}{l}\text { Aquisições/Incorporações } \\
\text { Investimento em Imobilizado, Investimento ou } \\
\text { Aquisição de Participações Societárias) }\end{array}$ \\
\hline
\end{tabular}

\subsubsection{Integrantes da Oferta}

O integrantes das ofertas são as pessoas que adquiriram as ações das empresas, e seus dados serão utilizados para explicar $\mathrm{H}_{0,2}$. Os valores absolutos de quantidade final de ações adquiridas, considerando inclusive os lotes suplementares, são apresentados nos comunicados de encerramento da oferta, conforme explicado na sessão 2.

Pelos estudos apontados nas teorias tratadas anteriormente, a razão de volume adquirido por tipo de participante, que possui diferentes horizontes de investimento, poderá sugerir uma relação que explique o retorno anormal de uma determinada ação.

A teoria dos fractais poderia apontar a existência desta relação entre a precificação e as informações dadas ao mercado em função do tipo de investidor, aliado ao seu horizonte de investimento (PETERS, 1991; PETERS, 1994; KAHNEMAN, 2003). Portanto, para cada tipo de integrante, espera-se comportamentos distintos, conforme exposto a seguir:

- Pessoas Físicas são os investidores comuns e também qualificados ${ }^{45}$, cuja participação na oferta não deverá surtir efeito em relação ao retorno anormal, pois os

\footnotetext{
${ }^{45}$ Investidores pessoas físicas, jurídicas e clubes de investimento cujas ordens individuais ou globais de investimento excedam $\mathrm{R} \$ 300.000,00$ (trezentos mil reais), fundos de investimento, fundos de pensão, entidades administradoras de recursos de terceiros registradas na CVM, entidades autorizadas a funcionar pelo BACEN, condomínios destinados à aplicação em carteira de títulos e valores mobiliários registrados na CVM e/ou na
} 
conhecimentos sobre a captação das empresas são somente aqueles disponibilizados pelos agentes colocadores da oferta;

- Clubes de Investimento, também seguem a mesma linha dos investidores pessoas físicas e não deverá surtir efeito em relação à oferta, pois os conhecimentos sobre a captação das empresas, também, são somente aqueles ofertados pelos agentes colocadores da oferta;

- Fundos de Investimento são agentes especializados que realizam análises detalhadas das ofertas, inclusive participando de Road Shows para determinar o montante de sua participação, que tende a ser mais assertiva;

- Entidades de Previdência Privada, também seguem a mesma linha dos Fundos de Investimento, são agentes especializados que realizam análises detalhadas das ofertas, inclusive participando de Road Shows para determinar o montante de sua participação, que tende a ser mais assertiva;

- Companhias Seguradoras, também seguem a mesma linha dos Fundos de Investimento e Entidades de Previdência Privada, são agentes especializados que realizam análises detalhadas das ofertas, inclusive participando de Road Shows para determinar o montante de sua participação, que tende a ser mais assertiva;

- Investidores Estrangeiros ${ }^{46}$, as empresas ofertantes fazem uso das possibilidades de colocação por meio de ADRs, para atingir o mercado norte-americano, principalmente na modalidade $144 \mathrm{~A}^{47}$, são agentes especializados que realizam

BM\&FBOVESPA, seguradoras, entidades de previdência complementar e de capitalização, investidores qualificados na forma da regulamentação da CVM e Investidores Estrangeiros.

${ }^{46}$ Investidores institucionais qualificados (qualified institutional buyers) nos Estados Unidos, conforme definidos na Regra 144A, e nos demais países (exceto nos Estados Unidos e no Brasil) considerados non-U.S. persons, de acordo com o Regulamento S, que invistam no Brasil em conformidade com os mecanismos da Resolução CMN 2.689, da Instrução CVM 325 e da Lei n ${ }^{\circ} 4.131$.

${ }^{47}$ É o nome dado a alternativa que regula as colocações privadas de ações nos EUA. Por ser destinado a investidores institucionais, não traz as exigências das adaptações contábeis da SEC (Securities and Exchange Commission) como exigência informações contábeis no padrão norte americano (US-GAAP). É negociado no sistema Private Offerings, Resales and Trading Trough Automated Linkage (PORTAL), que realiza a negociação das emissões privadas com liquidação via Depositary Trust Corporation (DTC). 
análises detalhadas das ofertas, inclusive participando de Road Shows para determinar o montante de sua participação, que tende a ser mais assertiva;

- Instituições Intermediárias Participantes do Consórcio de Distribuição são os Coordenadores da Oferta, Coordenadores Contratados e as Instituições Consorciadas, quando referidos em conjunto, o modo de sua participação na oferta é descrito no prospecto de cada oferta. É esperado que a sua participação esteja relacionada com o retorno anormal;

- Instituições Financeiras Ligadas à Companhia e/ou aos Participantes do Consórcio de Distribuição, são as partes relacionadas com o emissor ou com os distribuidores. É esperado que a sua participação esteja relacionado com o retorno anormal;

- Demais Instituições Financeiras, são as instituições que não estão ligadas com a oferta de distribuição, por serem agentes especializados que realizam análises detalhadas das ofertas, inclusive participando de Road Shows para determinar o montante de sua participação, é esperado que tenham uma participação mais assertiva;

- Demais Pessoas Jurídicas Ligadas à Companhia e/ou aos Participantes do Consórcio de Distribuição, são instituições que de algum modo possuem ligações com a companhia ou com os distribuidores. É esperado que a sua participação esteja relacionado com o retorno anormal;

- Demais Pessoas Jurídicas, também seguem a mesma linha dos investidores pessoas físicas e não deverá surtir efeito em relação a oferta, pois os conhecimentos sobre a captação da empresa, também, são somente aqueles ofertados pelos agentes colocadores da oferta;

- Sócios, Administradores, Empregados, Prepostos e demais pessoas ligadas à Companhia e/ou aos Participantes do Consórcio de Distribuição, o modo de sua participação na oferta é descrito no prospecto de cada oferta. É esperado que a sua participação esteja relacionado com o retorno anormal; 
- Outros Investidores são investidores que não se enquadram em nenhum dos demais tipos e também seguem a mesma linha dos investidores pessoas físicas e não deverá surtir efeito em relação a oferta, pois os conhecimentos sobre a captação da empresa, também, são somente aqueles ofertados pelos agentes colocadores da oferta; e

- Ações Recompradas no Âmbito das Atividades de Estabilização: A compra de ações de sua própria emissão é definida por Ross et al. (2002), como uma estratégia da empresa para a redução de custo de agência, para a sinalização de que suas ações estão subavaliadas pelo mercado. Ao se colocar a ação no mercado poderá ocorrer um período de instabilidade de liquidez, fato de algumas empresas assumirem que pode haver retorno anormal, por isso, adotam a prática de Recompra para a Estabilização, que inclusive, deve ser descrita no prospecto a forma como será operacionalizada.

A "tabela 5" a seguir, apresenta a codificação utilizada neste trabalho para identificar os diferentes tipos investidores participantes da oferta.

\begin{tabular}{ll}
\hline \multicolumn{1}{c}{ Código } & \multicolumn{1}{c}{ Investidores } \\
\hline PF & Pessoas Físicas \\
CI & Clubes de Investimento \\
FI & Fundos de Investimento \\
EPP & Entidades de Previdência Privada \\
CS & Companhias Seguradoras \\
IE & Investidores Estrangeiros \\
IIP & Instituições Intermediárias Participantes do Consórcio \\
& de Distribuição \\
IFL & Instituições Financeiras Ligadas à Companhia e/ou aos \\
DIF & Participantes do Consórcio de Distribuição \\
DPJL & Demais Instituições Financeiras \\
DPJ & $\begin{array}{l}\text { Demais Pessoas Jurídicas Ligadas à Companhia e/ou } \\
\text { Demais Pessoas Jurídicas }\end{array}$ \\
ADM & $\begin{array}{l}\text { Sócios, Administradores, Empregados, Prepostos e } \\
\text { demais pessoas ligadas à Companhia e/ou aos }\end{array}$ \\
OI & Participantes do Consórcio de Distribuição \\
REC & Outros Investidores \\
\hline Ações Recompradas no Âmbito das Atividades de \\
Estabilização
\end{tabular}

$\overline{\text { Tabela } 5 \text { - Classificação dos investidores participantes da oferta, Fonte próprio autor }}$ 


\subsubsection{Variáveis de controle}

As variáveis de controle são utilizadas por pesquisadores como fatores que minimizam os efeitos de interferência entre as variáveis dependente e independentes, utilizadas para qualquer processo investigatório (WOOLDRIDGE, 2010).

Sendo o intuito desta pesquisa a análise da interferência da destinação dos recursos nos retornos anormais é preciso isolar os efeitos, por meio de controles, para que as variáreis de interesse possam ser corretamente estudadas.

As variáveis de controle a serem incluídas no modelo são aquelas que de alguma forma podem influenciar as variáveis dependente e independentes, sendo a omissão de uma variável de controle um viés econométrico. Contudo a inclusão desordenada poderá tornar o modelo desnecessariamente complicado como, também, ao aumento da variância nas estimativas pela presença de variáveis irrelevantes ao modelo estudado (WOOLDRIDGE, 2010).

Assim, este trabalho utiliza variáveis de controle que são utilizados na literatura de finanças como possíveis determinantes de desempenho, tais variáveis estavam disponíveis nos prospectos de oferta pública de cada empresa, e provavelmente foram utilizados como material de análise pelos investidores participantes.

Para a escolha das variáveis foram utilizados os estudos de: Ritter e Welch (2002), Korajczyk et al. (1991), Silveira (2004), Myers e Majluf (1984), Kayo (2002), Brealey et al. (2008), Assaf, (2005), Lopes et al. (2010), Lopes e Galdi (2007) e Mcguire et al. (1984).

\subsubsection{Setor Econômico de Atuação}

De acordo com Ritter e Welch (2002) as condições de mercado é o principal fator para oferta pública. E, como visto anteriormente, as condições favoráveis de mercado, a maior exposição em publicidade, podem ser fator de abertura de capital. Assim, as condições do mercado 
apresentam a ideia de que as empresas escolhem o melhor momento de se ir a público captar recursos. As empresas adiam suas ofertas caso seja percebida subvalorizarão de seus papéis, conforme a teoria do market timing (KORAJCZYK et al.,1991).

Codificação adotada:

$$
\text { STR = Setor Econômico de Atuação }
$$

As empresas serão classificadas pelo setor econômico a que pertencem, conforme "tabela 6" definida pela BM\&FBovespa e apresentada nos prospectos.

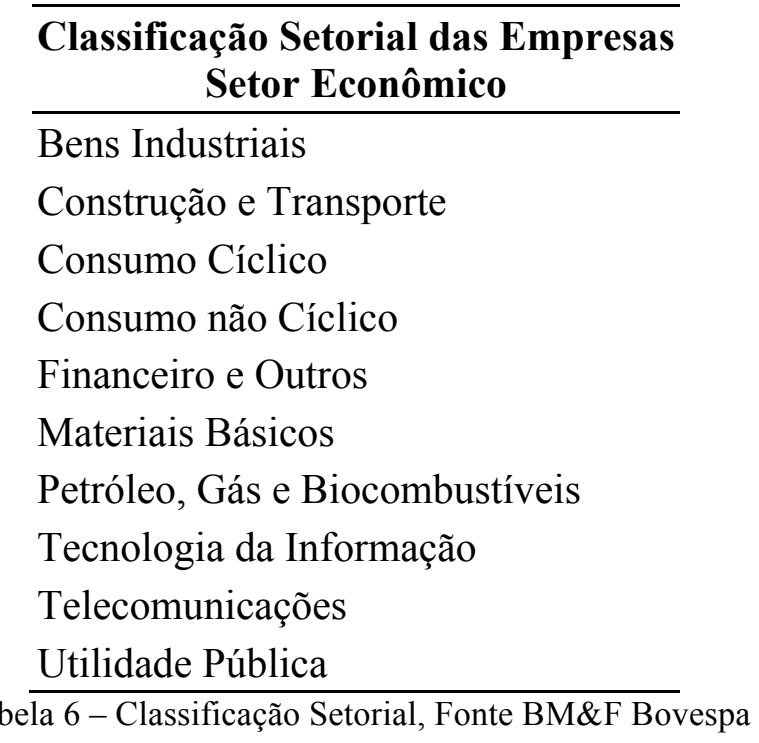

\subsubsection{Total de Ativos da Empresa}

Foi incluído como variável de controle o total de ativos da empresa em sua forma logarítmica natural. O total de ativos da empresa pode ser traduzido como seu tamanho e, portanto, poderia explicar a razão da entrada de investidores em uma oferta pública. De acordo com alguns estudos existe consenso de que o tamanho da empresa é refletido em seu desempenho no mercado de ações, Silveira (2004) identificou em seu estudo, por meio de dados em painel, que no período de 1994 a 2002, evidências da relação tamanho da empresa e desempenho.

Codificação adotada: 


\section{ATV: Total de Ativos da Empresa}

Os dados referentes ao total de ativos das empresas foram coletados dos prospectos de oferta pública e refletem a data de fechamento do balanço do último exercício social antes da data da oferta.

\subsubsection{Ebitda}

O lucro antes dos juros, imposto de renda, depreciação e amortização - LAJIDA, mais conhecido como EBITDA - earnings before interest, taxes, depreciation and amortization, é uma medida de desempenho financeiro que funciona como uma ferramenta significativa para comparar, periodicamente, o desempenho operacional e justificar as decisões administrativas adotadas pelas empresas.

Apesar da maioria dos prospectos de oferta pública apresentarem as seguinte ressalva:

“...segundo as Práticas Contábeis Adotadas no Brasil e IFRS, tampouco deve ser considerado isoladamente, ou como uma alternativa ao lucro líquido, como medida operacional, ou alternativa aos fluxos de caixa operacionais, ou como medida de liquidez. O EBITDA não tem uma definição padrão, podendo outras companhias calculá-lo de maneira diferente da nossa.”

O OFÍCIO-CIRCULAR/CVM/SNC/SEP nº 01/2007, que possui atualizações anuais, trata das informações que Diretores de Relações com Investidores e os Auditores Independentes devem prestar e garantir ao público. A descrição operacional de cálculo do Ebitda em seu tópico 1.9.7, também faz ressalva quanto a qualidade da mesma.

Assim, a opção pela utilização dessa variável de controle deve-se ao fato dos prospectos apresentarem esta informação como ferramenta de análise para os investidores, apesar de a ressalva estar sempre presente, mas nunca junto com a informação disponibilizada. Contudo foi realizada uma adaptação para apresentar sua margem, que é o Ebitda sobre a receita operacional líquida. 
Codificação adotada:

$$
\mathrm{ME}=\frac{\text { EBITDA }}{\text { RECEITA OPERACIONAL LÍQUIDA }}
$$

Os dados de Ebitda e da receita operacional líquida foram coletados dos prospectos de oferta pública e refletem a data de fechamento do balanço do último exercício social antes da data da oferta.

\subsubsection{Alavancagem}

De acordo com Myers e Majluf (1984) existe uma ordem para financiamento: primeiro os lucros retidos; segundo a dívida privada (empréstimos e financiamentos) e terceiro a emissão de dívida pública (debêntures) e ações. Já Kayo (2002) apresentou a relação entre capital de terceiros e capital próprio com o risco financeiro de uma empresa, maior o financiamento com capital de terceiros maior é a alavancagem e, portanto, maior o risco financeiro. Brealey et al. (2008) também apontam esse relação a partir de estudo desenvolvido para o período de 1989 à 2003.

Assim, a opção pela utilização dessa variável de controle decorre da disponibilização da informação nos prospectos aliado à fundamentação teórica de sua utilização. Em princípio se o resultado for superior a 1 denota maior grau de dependência financeira da empresa em relação aos recursos de terceiros (ASSAF; 2005).

A Codificação adotada:

$$
\text { DLPL }=\frac{\text { DÍVIDA LÍQUIDA }}{\text { PATRIMÔNIO LÍQUIDO }}
$$

Os dados de dívida líquida e do patrimônio líquido foram coletados dos prospectos de oferta pública e refletem a data de fechamento do balanço do último exercício social antes da data da oferta. 


\subsubsection{Retorno sobre os ativos (ROA, return on assets)}

De acordo com o estudo de Lopes et al. (2010) sobre recompra de ações e a análise fundamentalista, referente ao período de 1994 a 2006, o Retorno Sobre os Ativos (ROA) das empresas analisadas, serviram como indicadores de liquidez para segregar empresas winners das loser. Esse indicador também foi utilizado na pesquisa de Lopes e Galdi (2007).

Diversos outros pesquisadores relacionam o ROA como indicador de performance, neste sentido, Mcguire et al. (1984), avaliaram empresas norte-americanas utilizando indicadores de responsabilidade social da revista Fortune, e em relação ao desempenho financeiro utilizaram o ROA, aumento dos ativos, retornos ajustados, crescimento de vendas e o beta como fator de risco. Segundo Assaf (2005, p.119) o ROA:

“[...] pode ser interpretado como o custo financeiro máximo que uma empresa poderia incorrer em suas captações de fundos. Se uma empresa obtiver empréstimos a taxas de juros superiores ao retorno gerado por seus ativos, o resultado produzido pela aplicação desses fundos será evidentemente inferior à remuneração devida ao credor, onerando-se, dessa forma, a rentabilidade dos proprietários.

A Codificação adotada:

$$
\text { ROA }=\frac{\text { LUCRO OPERACIONAL }}{\text { ATIVO TOTAL }}
$$

Os dados de lucro operacional e do ativo total foram coletados dos prospectos de oferta pública e refletem a data de fechamento do balanço do último exercício social antes da data da oferta.

\subsubsection{Resumo das variáveis de estudo}

Resumo das variáveis utilizadas neste estudo estão descritas na "tabela 7" a seguir: 


\begin{tabular}{|c|c|c|}
\hline Código & Descrição & Operacionalização \\
\hline $\mathbf{A R}$ & Retorno anormal & $\mathrm{AR}_{\mathrm{i}, \mathrm{ipo}}=\left[\left(\frac{\mathrm{p}_{\mathrm{i}, \mathrm{F}, \mathrm{t}}}{\mathrm{p}_{\mathrm{i}, \mathrm{O}}}\right)-1\right]-\mathrm{R}_{\mathrm{ibov}, \mathrm{t}}$ \\
\hline GIR & Caixa ou Equivalentes Caixa & Percentual destinado da oferta \\
\hline PAS & Liquidação do Passivo & Percentual destinado da oferta \\
\hline FIN & Fornecimento de Crédito aos Clientes & Percentual destinado da oferta \\
\hline PRD & Modernização/Produção & Percentual destinado da oferta \\
\hline $\mathbf{A Q U}$ & Aquisições/Incorporações & Percentual destinado da oferta \\
\hline $\mathbf{P F}$ & Pessoas Físicas & Percentual adquirido da oferta \\
\hline CI & Clubes de Investimento & Percentual adquirido da oferta \\
\hline FI & Fundos de Investimento & Percentual adquirido da oferta \\
\hline EPP & Entidades de Previdência Privada & Percentual adquirido da oferta \\
\hline CS & Companhias Seguradoras & Percentual adquirido da oferta \\
\hline IE & Investidores Estrangeiros & Percentual adquirido da oferta \\
\hline IIP & Instituições Intermediárias Participantes da Distribuição & Percentual adquirido da oferta \\
\hline IFL & $\begin{array}{l}\text { IF Ligadas à Companhia e/ou aos Participantes da } \\
\text { Distribuição }\end{array}$ & Percentual adquirido da oferta \\
\hline DIF & Demais Instituições Financeiras & Percentual adquirido da oferta \\
\hline DPJL & $\begin{array}{l}\text { Demais PJs Ligadas à Companhia e/ou aos Participantes da } \\
\text { Distribuição }\end{array}$ & Percentual adquirido da oferta \\
\hline DPJ & Demais Pessoas Jurídicas & Percentual adquirido da oferta \\
\hline ADM & $\begin{array}{l}\text { Sócios, Administradores e demais pessoas ligadas à } \\
\text { Companhia e/ou aos Participantes da Distribuição }\end{array}$ & Percentual adquirido da oferta \\
\hline OI & Outros Investidores & Percentual adquirido da oferta \\
\hline REC & $\begin{array}{l}\text { Ações Recompradas no Âmbito das Atividades de } \\
\text { Estabilização }\end{array}$ & Percentual adquirido da oferta \\
\hline STR & Setor Econômico de Atuação & Fator Descritivo \\
\hline ATV & Total de Ativos da Empresa (tamanho) & $\mathrm{ATV}=\log ($ Ativo $)$ \\
\hline ME & $\begin{array}{l}\text { lucro antes dos juros, ir, depreciação e amortização sobre } \\
\text { receita operacional }\end{array}$ & $\mathrm{ME}=\frac{\text { EBITDA }}{\text { REC. OPER. LÍQUIDA }}$ \\
\hline DLPL & Alavancagem & DLPL $=\frac{\text { DÍVIDA LÍQUIDA }}{\text { PAT LÍQUIDO }}$ \\
\hline ROA & Retorno sobre o Ativo & ROA $=\frac{\text { LUCRO OPERACIONAL }}{\text { ATIVO TOTAL }}$ \\
\hline
\end{tabular}

Tabela 7 - Quadro resumo das variáveis, Fonte próprio autor 


\subsection{Modelo Econométrico}

Em face do problema de pesquisa anteriormente apresentado, que trata da destinação dos recursos em prospecto de oferta pública e a sua influência na decisão de compra dos investidores resultando em retornos anormais no primeiro dia da colocação, é necessário utilizar modelos de regressão. Tais modelos devem apresentar termos com interação que permitam identificar efeitos parciais entre as distintas variáveis.

Dessa forma, a regressão multivariada foi a estratégia escolhida para a validação das hipóteses, trata-se de uma técnica bastante difundida, que permite investigar a natureza das relações entre as variáveis. Tal intuito permite afirmar se são mutuamente independentes ou se uma ou mais variáveis são dependentes de outras.

Assim, é possível estabelecer relações entre variáveis que podem ser determinadas com o propósito de estabelecer previsões para os valores de uma ou mais variáveis em função das observações de outras variáveis (FÁVERO et al., 2009).

Wooldride (2010, p.64) afirma que a análise de regressão múltipla pode ser usada para construir modelos melhores para prever a variável dependente, sendo uma das vantagens a possibilidade de incorporar relações gerais de forma funcional.

$\mathrm{O}$ modelo geral da regressão utilizada para responder $\mathrm{H}_{0,1}$ é apresentado a seguir, de acordo com as variáveis definidas para o estudo.

$$
\begin{aligned}
& A R_{i}=\alpha_{i}+\beta_{1, i} G I R+\beta_{2, i} P A S+\beta_{3, i} F I N+\beta_{4, i} P R D+\beta_{5, i} A Q U+\beta_{6, i} S T R+\beta_{7, i} A T V \\
& +\beta_{8, i} M E+\beta_{9, i} D L P L+\beta_{10, i} R O A+\varepsilon_{i} \quad, i=1, \ldots, N
\end{aligned}
$$

Já o modelo geral da regressão utilizada para responder $\mathrm{H}_{0,2}$ é apresentado a seguir, de acordo com as variáveis definidas para o estudo.

$$
\begin{aligned}
& A R_{i}=\alpha_{i}+\beta_{1, i} P F+\beta_{2, i} C I+\beta_{3, i} F I+\beta_{4, i} E P P+\beta_{5, i} C S+\beta_{6, i} I E+\beta_{7, i} I I P \\
& \beta_{8, i} I F L+\beta_{9, i} D I F+\beta_{10, i} D P J L+\beta_{11, i} D P J+\beta_{12, i} A D M+\beta_{13, i} O I+\beta_{14, i} R E C \\
& +\beta_{15, i} A T V+\beta_{16, i} M E+\beta_{17, i} D L P L+\beta_{18, i} R O A+\varepsilon_{i} \quad, i=1, \ldots, N
\end{aligned}
$$


Para ambas as equações: o $\boldsymbol{\alpha}_{\boldsymbol{i}}$ representa o intercepto vertical, o $\boldsymbol{\varepsilon}_{\boldsymbol{i}}$ é o termo de erro da regressão, a variável dependente $\boldsymbol{A} \boldsymbol{R}_{\boldsymbol{i}}$ está explicada no item 3.3.1 e as variáveis de controle ATV, ME, DLPL e ROA estão explicadas no item 3.3.3.

Para o modelo que responde $\mathrm{H}_{0,1}$ as variáveis dependentes, GIR, PAS, FIN, PRD, AQU estão explicadas no item 3.3.2.1, Já para o modelo que trata $\mathrm{H}_{0,2}$, possui as variáveis PF, CI, FI, EPP, CS, IE, IIP, IFL, DIF, DPJL, DPJ, ADM, OI e REC que estão explicadas no item 3.3.2.2. 


\section{RESULTADOS}

$\mathrm{Na}$ "tabela 8" a seguir estão relacionadas as estatísticas descritivas referentes (i) a variável dependente, (ii) as variáveis independentes e (iii) as variáveis de controle utilizadas no estudo.

\begin{tabular}{|c|c|c|c|c|c|c|c|}
\hline Variáveis & $\mathrm{n}$ & Média & Desvio & Padrão & Mínimo & Máximo & Mediana \\
\hline$A R$ & 132 & 0,0208 & & 0,0733 & $-0,1718$ & 0,2745 & 0,0068 \\
\hline $\mathrm{AQU}$ & 132 & 0,3817 & & 0,3238 & 0,0000 & 1,0000 & 0,3725 \\
\hline PRD & 132 & 0,3304 & & 0,2858 & 0,0000 & 1,0000 & 0,3000 \\
\hline PAS & 132 & 0,1099 & & 0,2140 & 0,0000 & 1,0000 & 0,0000 \\
\hline GIR & 132 & 0,0958 & & 0,1500 & 0,0000 & 1,0000 & 0,0000 \\
\hline FIN & 132 & 0,0822 & & 0,2613 & 0,0000 & 1,0000 & 0,0000 \\
\hline $\mathrm{PF}$ & 132 & 0,0743 & & 0,0345 & 0,0005 & 0,2124 & 0,0824 \\
\hline CI & 132 & 0,0095 & & 0,0179 & 0,0000 & 0,1804 & 0,0057 \\
\hline FI & 132 & 0,1804 & & 0,1210 & 0,0000 & 0,6375 & 0,1754 \\
\hline $\mathrm{EPP}$ & 132 & 0,0130 & & 0,0383 & 0,0000 & 0,3418 & 0,0014 \\
\hline $\mathrm{CS}$ & 132 & 0,0003 & & 0,0012 & 0,0000 & 0,0092 & 0,0000 \\
\hline IE & 132 & 0,6467 & & 0,2282 & 0,0000 & 1,0079 & 0,6983 \\
\hline IIP & 132 & 0,0116 & & 0,0585 & 0,0000 & 0,6185 & 0,0000 \\
\hline IFL & 132 & 0,0043 & & 0,0316 & 0,0000 & 0,3456 & 0,0000 \\
\hline DIF & 132 & 0,0145 & & 0,0363 & 0,0000 & 0,3759 & 0,0056 \\
\hline DPJL & 132 & 0,0270 & & 0,1221 & 0,0000 & 0,8953 & 0,0000 \\
\hline $\mathrm{DPJ}$ & 132 & 0,0359 & & 0,1318 & 0,0000 & 0,9348 & 0,0023 \\
\hline $\mathrm{ADM}$ & 132 & 0,0144 & & 0,0516 & 0,0000 & 0,3061 & 0,0000 \\
\hline OI & 132 & 0,0060 & & 0,0277 & 0,0000 & 0,1986 & 0,0000 \\
\hline $\mathrm{REC}$ & 132 & $-0,0378$ & & 0,0573 & $-0,1550$ & 0,0000 & 0,0000 \\
\hline ATV & 132 & 6,1517 & & 0,8349 & 4,0813 & 8,8504 & 6,0506 \\
\hline $\mathrm{ME}$ & 132 & 0,1656 & & 0,9167 & $-9,9224$ & 0,8726 & 0,1909 \\
\hline DLPL & 132 & 1,0844 & & 3,0387 & $-10,8594$ & 21,8446 & 0,4631 \\
\hline $\mathrm{ROA}$ & 132 & 0,0534 & & 0,1024 & $-0,1798$ & 0,9097 & 0,0374 \\
\hline
\end{tabular}

Tabela 8 - Estatísticas descritivas do estudo, Fonte próprio autor

As informações da tabela anterior apresentam indícios de que a base de dados gerada, a partir dos dados coletados, pode estar sujeita a problemas com valores discrepantes $\left(\right.$ outliers $^{48}$ ).

No procedimento estatístico verificou-se a assimetria positiva na variável dependente, retorno anormal, resultante do primeiro dia de negociação da ação. Assim, foi necessário adotar um critério para remover da amostra os valores extremos, de forma que minimizasse possíveis problemas relativos à inferência nos resultados. $\mathrm{O}$ critério utilizado baseou-se no intervalo de variação do atributo, onde $\bar{X}_{i}-2 * d p\left(\bar{X}_{i}\right)<X_{i}<\bar{X}_{i}+1,75 * d p\left(\bar{X}_{i}\right)$.

\footnotetext{
${ }^{48}$ Os dados outliers implicam, tipicamente, em prejuízos da interpretação dos resultados dos testes estatísticos aplicados às amostras.
} 
Quanto às demais variáveis, não foram verificadas distorções consideráveis para este trabalho, o que permitiu que a apresentação de suas medidas descritivas fossem exibidas considerando a amostra como um todo.

Dessa forma, conforme o critério adotado, foram eliminadas as seguintes empresas da amostra estudada:

\begin{tabular}{lrr}
\hline Empresas descartadas da amostra & Data das ofertas & Retorno anormal \\
\hline Amil & Outubro/2007 & $15,02 \%$ \\
Anhanguera Educ. & Março/2007 & $21,13 \%$ \\
Brasil Insurance & Outubro/2010 & $26,15 \%$ \\
GVT SA & Fevereiro/2007 & $27,45 \%$ \\
Le Lis Blanc & Abril/08 & $-17,18 \%$ \\
MRV Engenharia & Julho/2007 & $18,20 \%$ \\
Redecard & Julho/2007 & $24,02 \%$ \\
Rodobens & Janeiro/2007 & $15,31 \%$ \\
Sao Martinho & Fevereiro/2007 & $19,09 \%$ \\
\hline
\end{tabular}

Tabela 9 - Outliers removidos da amostra. Fonte próprio autor

O histograma (Apêndice 2), juntamente com o teste de Anderson-Darling para averiguação de normalidade referente à distribuição da variável dependente (AR), componente da base de dados, em seu teste estatístico, cujo p-valor indicou um resultado de 0.0005776 , não revelou a existência de normalidade.

Quanto a isso, Rodrigues (2007, p. 107) destaca que: "não é necessária a distribuição normal em grandes amostras, pois os testes efetuados apresentam resultados assintóticos, ou seja, mesmo que os resíduos não tenham distribuição normal, a distribuição dos coeficientes será próxima da normal”. Em consonância com esse critério, o dado componente da amostra e seus resultados não estariam invalidados.

Em relação às variáveis independentes e as variáveis de controle, as informações descritas na “tabela 10" apresentam os testes de correlação. Segundo Fávero et al. (2009), "o objetivo da correlação é quantificar a força de relação existente entre dois vetores de variáveis, representados pelas dependentes e independentes". 
Dessa forma, é possível identificar a estrutura, aparentemente, ótima de variáveis que maximiza as relações entre elas, sendo possível desenvolver uma combinação linear para cada conjunto de variáveis.

A análise sugere que estes sejam os dados adequados, para testar a hipótese $\mathrm{H}_{0,1}$, por não haver evidência de multicolinearidade entre as variáveis. Ainda, segundo Fávero et al. (2009), "muitas variáveis explicativas em um modelo podem apresentar comportamentos semelhantes, ou seja, entre algumas delas pode existir uma correlação elevada, em decorrência da seleção da amostra coletada por conveniência ou do número insuficiente de observações."

\begin{tabular}{|c|c|c|c|c|c|c|c|c|c|}
\hline $\mathrm{AR}$ & $\mathrm{AQU}$ & PRD & PAS & GIR & FIN & ATV & $\mathrm{ME}$ & DLPL & $\mathrm{ROA}$ \\
\hline \begin{tabular}{l|l}
$A R$ & 1.0000
\end{tabular} & & & & & & & & & \\
\hline $\mathrm{AQU} \mid 0.0608$ & 1.0000 & & & & & & & & \\
\hline PRD | 0.0199 & -0.4614 & 1.0000 & & & & & & & \\
\hline PAS $\quad 1-0.0952$ & -0.3601 & -0.1620 & 1.0000 & & & & & & \\
\hline GIR | 0.0531 & -0.1466 & -0.1441 & -0.0729 & 1.0000 & & & & & \\
\hline FIN $1-0.0493$ & -0.3572 & -0.3061 & -0.1545 & -0.1688 & 1.0000 & & & & \\
\hline ATV $1-0.0588$ & -0.0489 & -0.1628 & 0.1077 & 0.0818 & 0.1038 & 1.0000 & & & \\
\hline \begin{tabular}{l|l}
$\mathrm{ME}$ & 0.1386
\end{tabular} & 0.3855 & -0.1439 & -0.1936 & -0.1058 & -0.1019 & 0.0921 & 1.0000 & & \\
\hline DLPL $\mid-0.1404$ & -0.3155 & 0.1423 & -0.0323 & 0.0880 & 0.2122 & 0.0263 & -0.1397 & 1.0000 & \\
\hline \begin{tabular}{l|l}
$\mathrm{ROA}$ & 0.0409
\end{tabular} & 0.2814 & -0.0547 & -0.1225 & -0.1195 & -0.1208 & -0.0355 & 0.2524 & -0.1875 & 1.0000 \\
\hline
\end{tabular}

Tabela 10 - Teste de Correlação entre as variáveis de estudo de $\mathrm{H}_{0,1}$

Em relação às variáveis independentes e as variáveis de controle para $\mathrm{H}_{0,2}$, as informações descritas no Apêndice 3 apresentam os testes de correlação. A análise sugere que estes sejam os dados adequados, para testar a hipótese $\mathrm{H}_{0,2}$, por não haver evidência de multicolinearidade entre as variáveis, à exceção da relação entre a variável IIP (Instituições Intermediárias Participantes da Distribuição) e a variável ADM (Sócios, Administradores e demais pessoas ligadas à Companhia e/ou aos Participantes da Distribuição), cuja correlação atingiu 0.5006, mas que não é estatisticamente significante para o resultado final deste trabalho.

O resultados das regressões com a variáveis são apresentados a seguir:

$\mathrm{O}$ modelo $\mathrm{H}_{0,1}$ foi testado em duas especificações distintas, em ambos os casos o modelo é de pooling e não considera o efeito do tempo sobre a relação estudada. O primeiro teste considerou o modelo $\mathrm{H}_{0,1}$ sem as variáveis de controle, enquanto o segundo teste considerou o modelo completo, com as variáveis de controle conforme descrito no item 3.3.4. 
Conforme os resultados apurados na "Tabela 11", sem as variáveis de controle, observa-se que todas as variáveis independentes não possuem significância estatística no modelo, o que sugere não haver relação entre o Retorno Anormal (RA) no primeiro dia de negociação e a destinação dos recursos apresentada nos prospectos de oferta pública. Além disso, o $\mathrm{R}^{2}$ foi igual a 0.01319 o que indica a não relevância do modelo estudado.

\begin{tabular}{|c|c|c|c|c|}
\hline & Coeficiente & Desvio Padrão & t valor & $\operatorname{Pr}(>|t|)$ \\
\hline Intercepto & 0.002612 & 0.013261 & 0.197 & 0.844 \\
\hline GIR & 0.026559 & 0.034787 & 0.763 & 0.447 \\
\hline PAS & -0.011288 & 0.026800 & -0.421 & 0.674 \\
\hline FIN & 0.005726 & 0.022144 & 0.259 & 0.796 \\
\hline PRD & -0.008756 & 0.016381 & -0.535 & 0.594 \\
\hline $\mathrm{AQU}$ & 0.007593 & 0.019933 & 0.381 & 0.704 \\
\hline $\mathrm{N}=$ & 117 & $R^{2}=$ & 0.01319 & \\
\hline F-statistic & 0.3129 & $p$-valor $=$ & 0.9044 & \\
\hline Min & $1 Q$ & Median & $3 Q$ & $\operatorname{Max}$ \\
\hline-0.161809 & -0.031237 & -0.003946 & 0.024152 & 0.156378 \\
\hline
\end{tabular}

Tabela 11 - Modelo do estudo $\mathrm{H}_{0,1}$ sem variáveis de controle, Fonte próprio autor

Já os resultados apurados na "tabela 13", com as variáveis de controle, mostra que todas as variáveis independentes, utilizadas para explicar o modelo, também, não possuem significância estatística.

Tal evidência sugere, também, que as destinações dos recursos descritas nos prospectos de oferta pública não surtem efeito frente aos investidores e não provoca o Retorno Anormal (RA) das ações no primeiro dia de negociação.

A variável de controle STR (Tecnologia da Informação) apresentou significância estatística a 5\%, demonstrando-se relacionada ao Retorno Anormal (RA). É possível que o risco setorial esteja diretamente relacionado ao retorno anormal, contudo havia na amostra apenas uma empresa do setor Tecnologia da Informação, o que não permite avançar com tal inferência, veja na "tabela 12" a seguir, a quantidade de ofertas por setor no período da amostra, após a remoção dos outliers. 


\begin{tabular}{lr}
\hline Setor Econômico & Empresas \\
\hline Bens Industriais & 3 \\
Construção e Transporte & 36 \\
Consumo Cíclico & 18 \\
Consumo não Cíclico & 20 \\
Financeiro e Outros & 26 \\
Materiais Básicos & 10 \\
Petróleo, Gás e Biocombustíveis & 6 \\
Tecnologia da Informação & 1 \\
Telecomunicações & 1 \\
Utilidade Pública & 2 \\
Total & $\mathbf{1 2 3}$ \\
\hline bela 12 - Quantidade de Ofertas por Setor, Fonte Próprio Autor
\end{tabular}

As variáveis de controle ATV (Total de Ativos da Empresa) e ME (Margem de Ebitida sobre Receita Operacional Líquida) não surtiram efeito frente ao modelo. Para o indicador ME tal evidência era esperada, uma vez que, o indicador Ebitda é apresentado nos prospectos com ressalvas sobre a sua eficiência quanto indicador de desempenho de uma empresa, conforme Ofício-Circular relatado no item 3.3.3.3 deste trabalho. Já a variável de controle ATV havia apresentado relação frente aos desempenhos das ações no mercado, conforme evidenciado por Silveira (2004), mas neste trabalho não foi possível observar tal fenômeno.

Quanto a variável de controle DLPL foi observado uma significância estatística no modelo de $1 \%$, ou seja, a relação de dívida líquida sobre o patrimônio líquido parece ser a que mais explica o retorno anormal, dentro do modelo. Dessa forma, podemos concluir que o indicar é possivelmente utilizado para avaliação de preço de uma ação, principalmente no momento inicial de negociação das ações, onde a formação de preço pelo mercado ainda não está clara.

Tal observação vai ao encontro de estudos anteriores como de Myers e Majluf (1984) que evidenciaram a existência de uma ordem de preferência para o financiamento de uma empresa e, também, o estudo de Kayo (2002) que apresentou uma relação entre capital de terceiros e capital próprio com o risco financeiro de uma empresa, onde quanto maior o financiamento com o capital de terceiros maior é a alavancagem.

Por fim, o ROA (retorno sobre os ativos) apresentou-se explicando os retornos anormais ao nível de significância estatística de 5\%. Estudos anteriores como os de Mcguire et al. (1984), 
Lopes e Galdi (2007) e Lopes et al. (2010) este último sobre a recompra de ações por análise fundamentalista, também sugeriram o ROA como indicador de liquidez para segregar empresas winners das loser.

\begin{tabular}{|c|c|c|c|c|}
\hline & Coeficiente & Desvio Padrão & t valor & $\operatorname{Pr}(>|t|)$ \\
\hline Intercepto & -0.0248140 & 0.0481679 & -0.515 & 0.607538 \\
\hline GIR & 0.0532296 & 0.0373757 & 1.424 & 0.157389 \\
\hline PAS & -0.0253463 & 0.0273079 & -0.928 & 0.355471 \\
\hline FIN & 0.0122387 & 0.0259499 & 0.472 & 0.638182 \\
\hline PRD & -0.0130447 & 0.0163576 & -0.797 & 0.426993 \\
\hline $\mathrm{AQU}$ & -0.0260513 & 0.0216558 & -1.203 & 0.231719 \\
\hline STR[T.Construção e Transporte] & -0.0061845 & 0.0314346 & -0.197 & 0.844414 \\
\hline STR[T.Consumo Cíclico] & 0.0276919 & 0.0326183 & 0.849 & 0.397848 \\
\hline STR[T.Consumo não Cíclico] & 0.0203184 & 0.0324819 & 0.626 & 0.532993 \\
\hline STR[T.Financeiro e Outros] & 0.0042315 & 0.0330525 & 0.128 & 0.898378 \\
\hline STR[T.Materiais Básicos] & -0.0136851 & 0.0356978 & -0.383 & 0.702235 \\
\hline STR[T.Petróleo, Gás e Biocombu] & 0.0002766 & 0.0380501 & 0.007 & 0.994214 \\
\hline STR[T.Tecnologia da Informação] & 0.1214584 & 0.0602915 & 2.015 & 0.046536 \\
\hline STR [T.Telecomunicões ] & -0.0320508 & 0.0628450 & -0.510 & 0.611133 \\
\hline STR[T.Utilidade Pública] & 0.0112008 & 0.0495395 & 0.226 & 0.821569 \\
\hline ATV & 0.0049645 & 0.0063827 & 0.778 & 0.438450 \\
\hline $\mathrm{ME}$ & 0.0084602 & 0.0053725 & 1.575 & 0.118357 \\
\hline $\mathrm{DLPL}$ & -0.0059695 & 0.0017302 & -3.450 & 0.000811 \\
\hline $\mathrm{ROA}$ & 0.1040491 & 0.0510655 & 2.038 & 0.044133 \\
\hline $\mathrm{N}=$ & 104 & $R^{2}=$ & 0.2246 & \\
\hline F-statistic $=$ & 1.674 & $p$-valor $=$ & 0.05592 & \\
\hline Min & $1 Q$ & Median & 30 & Max \\
\hline-0.135860 & -0.024603 & -0.000389 & 0.024550 & 0.142997 \\
\hline$*$ - Significante em $10 \%(0,10)$ & \multicolumn{2}{|c|}{$* *$ - Significante em $5 \%(0,05)$} & \multicolumn{2}{|c|}{$* * *$ - Significante em $1 \%(0,01)$} \\
\hline
\end{tabular}

Tabela 13 - Modelo do estudo $\mathrm{H}_{0,1}$ com variáveis de controle, Fonte próprio autor

Com o intuito de melhorar o resultado estatístico $F$, o modelo $\mathrm{H}_{0,1}$, também foi testado considerando as variáveis independentes em base logarítmica aplicada sobre os valores absolutos juntamente com os testes de heterocedasticidade. Tal feito tornou o modelo mais robusto, contudo a análise dos resultados permaneceram inalterados e, por este motivo não encontram-se listados neste trabalho.

$\mathrm{O}$ modelo $\mathrm{H}_{0,2}$ foi testado, também, em duas especificações distintas. Em ambos os casos o modelo é de pooling e não considera o efeito do tempo sobre a relação estudada. O primeiro teste considerou o modelo $\mathrm{H}_{0,2}$ sem as variáveis de controle, enquanto o segundo teste considerou o modelo completo, com as variáveis de controle conforme descrito no item 3.3.4. 
Conforme os resultados apurados na "Tabela 14", sem as variáveis de controle, observa-se que as variáveis independentes PF, CI, FI, EPP, IE, IIP, IFL, DIF, DPJL, DPJ, e OI não possuem significância estatística no modelo, o que sugere não haver relação entre o Retorno Anormal (RA) no primeiro dia de negociação e a entrada desses investidores na oferta pública de ações. Contudo as variáveis independentes CS com retorno negativo ao nível de significância de 10\%, ADM com retorno negativo ao nível de significância de 5\% e REC com retorno positivo ao nível de significância de $1 \%$, aparentemente mostraram relevância estatística. $\mathrm{O} \mathrm{R}^{2}$ foi igual a $0.2713 \mathrm{o}$ que aparentemente indica a relevância do modelo estudado.

\begin{tabular}{|c|c|c|c|c|c|}
\hline & Coeficiente & Desvio Padrão & estatística t & $\operatorname{Pr}(>|t|)$ & \\
\hline Intercepto & 0.032079 & 0.034968 & 0.917 & 0.360993 & \\
\hline $\mathrm{PF}$ & -0.195880 & 0.153943 & -1.272 & 0.205957 & \\
\hline CI & 0.049793 & 0.277973 & 0.179 & 0.858172 & \\
\hline FI & 0.019537 & 0.055993 & 0.349 & 0.727831 & \\
\hline $\mathrm{EPP}$ & 0.054120 & 0.128779 & 0.420 & 0.675135 & \\
\hline CS & -6.197537 & 3.693860 & -1.678 & 0.096279 & \\
\hline IE & 0.019044 & 0.044852 & 0.425 & 0.671972 & \\
\hline IIP & 0.053547 & 0.097138 & 0.551 & 0.582606 & \\
\hline IEL & -0.020207 & 0.151394 & -0.133 & 0.894070 & \\
\hline $\mathrm{DIF}$ & 0.160507 & 0.128844 & 1.246 & 0.215553 & \\
\hline DPJL & -0.015086 & 0.061955 & -0.244 & 0.808075 & \\
\hline $\mathrm{DPJ}$ & 0.001688 & 0.006570 & 0.257 & 0.797770 & \\
\hline $\mathrm{ADM}$ & -0.317506 & 0.109660 & -2.895 & 0.004584 & $\star \star$ \\
\hline OI & -0.100500 & 0.169631 & -0.592 & 0.554776 & \\
\hline REC & 0.393231 & 0.097508 & 4.033 & 0.000103 & $\star \star \star$ \\
\hline $\mathrm{N}=$ & 108 & $R^{2}=$ & 0.2713 & & \\
\hline F-statistic $=$ & 2.872 & $p$-valor $=$ & 0.001043 & & \\
\hline Min & $1 Q$ & Median & $3 Q$ & $\operatorname{Max}$ & \\
\hline-0.122541 & -0.030551 & -0.005623 & 0.020684 & 0.134044 & \\
\hline \multicolumn{2}{|c|}{$*$ - Significante em $10 \%(0,10)$} & $* *$ - Significante em $5 \%(0$, & 05) $* * *$ - Significa & te em $1 \%(0,01)$ & \\
\hline
\end{tabular}

Tabela 14 - Modelo do estudo $\mathrm{H}_{0,2}$ sem variáveis de controle. Fonte próprio autor

De acordo com a "tabela 15", as Companhias Seguradoras (CS) participaram de 17 ofertas públicas de ações, enquanto os sócios, administradores e demais pessoas ligadas à companhia e/ou aos participantes da distribuição (ADM) estiveram presentes na aquisição de ações em 44 ofertas públicas de ações.

Já os procedimentos de recompra de ações no âmbito das atividades de estabilização de preços (REC) foram realizados em 45 ofertadas de distribuição de ações, era esperado que o 
efeito sobre o retorno anormal se fizesse presente com esta variável, uma vez que, o procedimento somente é iniciado caso ocorra uma momentânea variação de liquidez a partir do lançamento da ação.

Assim, podemos considerar o resultado apontado pelo modelo estatístico como aceito para as variáveis independentes $\mathrm{CS}, \mathrm{ADM}$ e REC, pois a quantidade de participantes pode ser considerada satisfatória, frente ao tamanho da amostra.

\begin{tabular}{cc}
\hline Participantes das Ofertas & Quantidade de Ofertas \\
\hline PF & 123 \\
CI & 122 \\
FI & 120 \\
EPP & 97 \\
CS & 17 \\
IE & 122 \\
IIP & 27 \\
IFL & 10 \\
DIF & 94 \\
DPJL & 30 \\
DPJ & 121 \\
ADM & 44 \\
OI & 22 \\
REC & 45 \\
\hline Tabela 15 - Relaça de Participantes das Ofertas. Fonte próprio autor
\end{tabular}

Os resultados apurados na "tabela 16", com as variáveis de controle, mostra que dentre as variáveis dependentes e de controle, utilizadas para explicar o modelo $\mathrm{H}_{0,2}$, possuem significância estatística ADM, REC, STR e ROA.

Tal evidência sugere, também, que o perfil dos investidores participantes de uma oferta não surte efeito como um todo frente ao Retorno Anormal (RA) das ações no primeiro dia de negociação. $\mathrm{O} \mathrm{R}^{2}$ foi igual a 0.3409 o que aparentemente indica a relevância do modelo estudado.

A variável de controle STR (Tecnologia da Informação), mais uma vez apresentou significância estatística à $10 \%$, porém como explicado anteriormente, com somente uma 
empresa, a Bematech, a relação do setor com o retorno anormal invalida a argumentação de análise.

Quanto a variável independente ADM, que corresponde aos sócios, administradores e demais pessoas ligadas à companhia e/ou aos participantes da distribuição, a variável apresentou significância estatística a $10 \%$, ou seja, o retorno anormal tende a ser negativo quando pessoas relacionadas à empresa quando participam da oferta. Já a variável independente REC, mais uma vez mostrou retorno positivo.

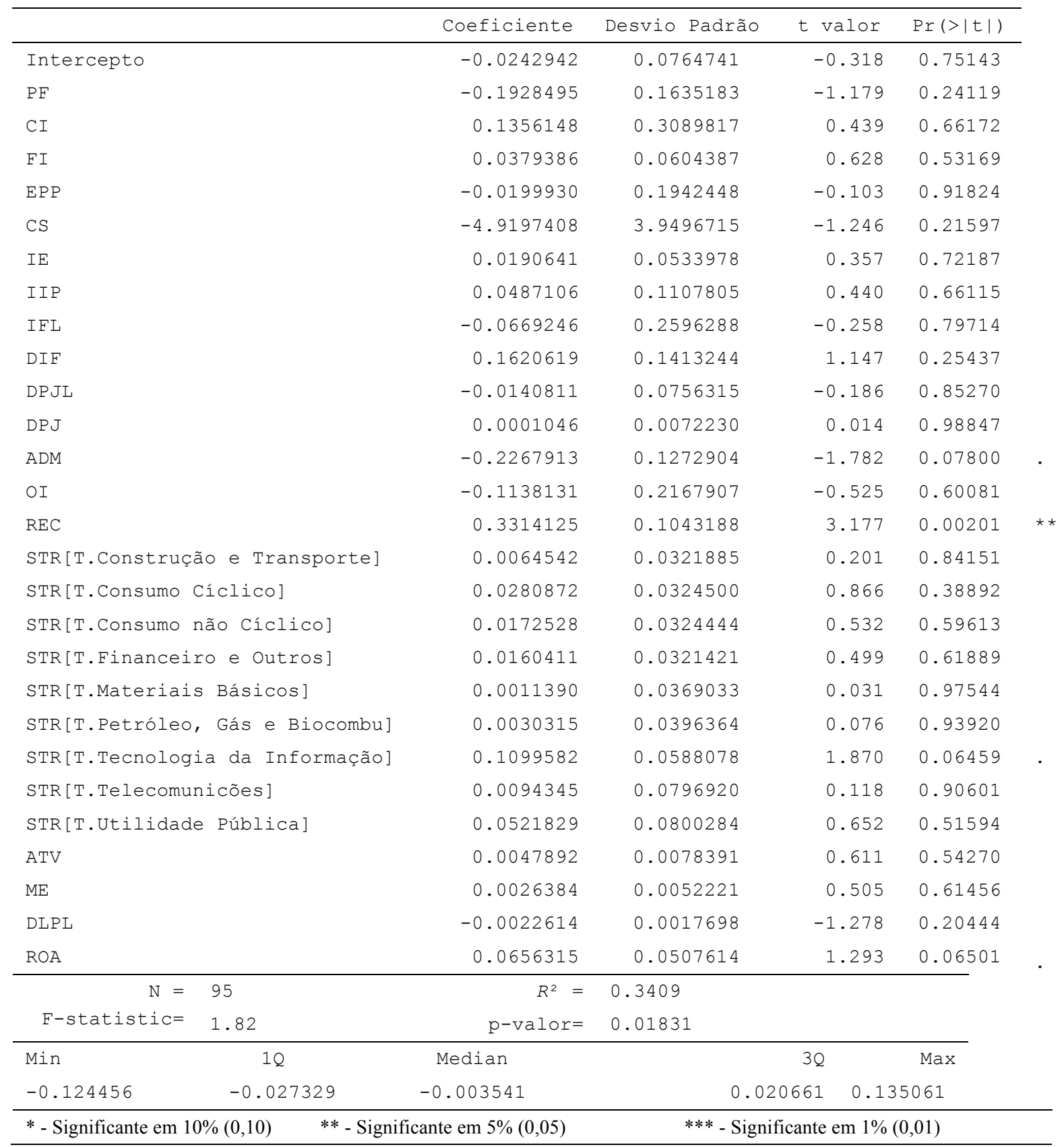

Tabela 16 - Modelo do estudo $\mathrm{H}_{0,2}$ com variáveis de controle. Fonte próprio autor 
Por fim, assim como apontados em estudos anteriores, o ROA (retorno sobre os ativos) apresentou-se explicando os retornos anormais ao nível de significância estatística de 10\%. Tal variável controle atendeu ao comportamento esperado como àqueles descritos por Mcguire et al. (1984), Lopes e Galdi (2007) e Lopes et al. (2010). 


\section{CONSIDERAÇÕES FINAIS}

Essa pesquisa teve como objetivo estudar a relação entre a destinação dos recursos de captação de recursos em oferta primária de ações com o retorno anormal das ações no primeiro dia de negociação. Além disso, havia o objetivo adicional de buscar evidências sobre os investidores participantes da oferta e o os seus efeitos sobre o retorno anormal.

Para isso, foi proposto o uso das informações sobre a destinação dos recursos captados das ofertas públicas de distribuições de ações dos períodos de janeiro de 2007 a dezembro de 2011. Bem como, as informações dos participantes das ofertas disponibilizados no comunicado de encerramento das ofertas.

A análise dos dados iniciais possibilitou identificar problemas que poderão ser contornados no futuro. Uma vez que, a obrigatoriedade de apresentação da destinação dos recursos, dada pela ICVM 400 e suas atualizações posteriores, são feitas em valores absolutos ou em percentuais pelas empresas. Algumas dessas medidas podem ser (i) explicitar melhor o conceito de destinação dos recursos, (ii) criar mecanismos mais claros para avaliar a qualidade das informações prestadas pelas companhias, pois a forma de apresentação variava entre os prospectos, (iii) criar mecanismos de controle posterior à oferta para conferência da utilização dos recursos e suas justificativas.

Os dados coletados nos prospectos e no comunicado de encerramento das ofertas foram utilizados como base para os modelos econométricos apresentado na seção 3. As estimativas do modelo $\mathrm{H}_{0,1}$ sugerem que não há relação entre as variações dos preços das ações nos primeiro dia de negociação no pregão e as destinações dos recursos captados com a oferta primária. Assim rejeitou-se a hipótese nula. Porém o modelo funcionou para as variáveis de controle que trazem indicadores financeiros como ROA e a alavancagem (dívida líquida sobre patrimônio líquido)

Também, não foram encontradas evidências fortes o bastante para explicar $\mathrm{H}_{0,2}$ que trata do momento posterior ao lançamento das ações, por meio do comunicado ao mercado de encerramento da oferta. Nestas informações esperava-se a relação entre os participantes da oferta e os retornos anormais, contudo somente foi possível verificar uma relação negativa 
entre o retorno e a participação dos sócios, administradores e demais pessoas ligadas à companhia e/ou aos participantes da distribuição. Em relação aos procedimentos de recompra de ações no âmbito das atividades de estabilização de preços foi possível estabelecer uma relação com os retornos anormais. Mais uma vez o modelo funcionou para a variável de controle ROA, informação compatível com as teorias de finanças.

Acredita-se que a dificuldade em se obter resultados mais conclusivos e que pudessem corroborar com as teorias de finanças deve-se ao fato, pelo menos em parte, da má qualidade das informações divulgadas nos prospectos de oferta pública quanto à destinação dos recursos. Além disso, ao analisar os prospectos foi possível observar padrões determinados pelos coordenadores das ofertas, ou seja, dado um banco de investimento coordenador, praticamente todos os prospectos sob sua responsabilidade seguiam o mesmo padrão informacional. Durante os estudos realizados para este trabalho, não foi possível encontrar literatura que trata deste aspecto.

Como sugestões para novos estudos podem ser considerados (i) a ampliação do universo de empresas estudadas, sendo fundamental, neste caso, que se observe o período pré e pós implementação da ICVM 400 de 29 de dezembro de 2003; e (ii) acompanhar nos relatórios financeiros subsequentes à oferta, publicados pelas empresas, para identificar a efetiva utilização dos recursos captados, bem como o efeito de variação do preço das ações nos períodos subsequentes. 


\section{REFERÊNCIAS BIBLIOGRÁFICAS}

AGGARWAL, R., LEAL, R.; HERNANDEZ L. The aftermarket performance of initial public offerings in Latin America, Financial Management, 22, pp. 42-53., 1993.

ANBIMA - Associação Brasileira das Entidades dos Mercados Financeiros e de Capitais. Disponível em $<$ http://www.anbima.com.br>. Acesso em novembro de 2011.

ANG, J., BRAU. J., 2003, "Concealing and confounding adverse signals: Insider wealthmaximizing behavior in the IPO process", Journal of Financial Economics 40, 149-172.

ASSAF NETO, A.; Finanças Corporativas e Valor. $2^{\circ}$ ed.; São Paulo: Atlas, 2005.

. Mercado Financeiro. $9^{\circ}$ ed.; São Paulo: Atlas, 2009.

ASSAF NETO, A., LIMA, F. G., Araújo, A.M. P., A Realidade da Concentração do Capital no Brasil: Um Estudo Comparativo com Outras Economias Emergentes. Disponível no site da Fipecafi e no site do Instituto Assf, 2006.

BACEN - Banco Central do Brasil. Disponível em <http://www.bcb.gov.br $>$. Acesso em abril de 2012.

BENVENISTE, L. M.; SPINDT, P. A. How Investments Bankers Determine the Offer Price and Allocation of New Issues. Journal of Financial Economics 24, 1989. 343-362.

BM\&FBovespa - Bolsa de Valores de São Paulo. Disponível em $<$ http://www.bmfbovespa.com.br>. Acesso em setembro de 2011.

BODIE, Z; KANE, A; MARCUS, A.J.; Fundamentos de Investimentos, 3. ed. Porto Alegre: Bookman, 2000.

BRADLEY, D.; JORDAN, B.; RITTER, J. R., "The quiet period goes out with a bank", Journal of Finance 58, 1-36; 2003.

BRAU, J. C.; FAWCETT, S. E. Initial Public Offerings: An Analysis of Theory and Practice. The Journal of Finance, Feb 2006. 399-436.

BREALEY, R. A., MYERS S. C.; Finanças Corporativas: Financiamento e Gestão de Risco; $1^{\circ}$ ed.; Bookman, 2005.

BRITO, R. D.; LIMA, M. R.; A Escolha da Estrutura de Capital sob Fraca Garantia Legal; Revista Brasileira de Economia; Rio de Janeiro, V. 59, N. 2, P. 177- 208; 2005. 
CASAGRANDE NETO, H. ; SOUZA, A. L. ; e ROSSI, M. C.; Abertura de capitais de empresas no Brasil: um enfoque prático 4. ed. São Paulo: Atlas, 2010.

CAVAlCANTE, F.; MISUMI, J. Y.; Mercado de Capitais, 6. ed. São Paulo: Campus, 2002.

CAVAlCAnTE, F.; MISUMi, J. Y.; RUDGE, L. F.; Mercado de Capitais - O que é, como funciona, 7. ed. São Paulo: Campus, 2009.

CORBETT, J.; JENKINSON, T.; "How is Investment Financed? A Study of Germany, Japan, UK and US"; The Manchester School, Vol 65:1, pp 69-93, 1997.

CVM - Comissão de Valores Mobiliários. Disponível em <http://www.cvm.gov.br >. Acesso em abril de 2012.

DALMÁCIO, Flávia Zóboli. Mecanismos de governança e acurácia das previsões dos analistas do mercado brasileiro : uma análise sob a perspectiva da teoria de sinalização. Tese de Doutorado. Faculdade Economia, Administração e Ciências Contábeis; Universidade de São Paulo. São Paulo, 2009.

DAMODARAN, A.; Avaliação de Investimentos: ferramentas e técnicas para a determinação de valor de qualquer ativo. 1. ed. Rio de Janeiro: Atlas, 2010.

FAMA, E. F. Efficient Capital Markets: A review of theory and empirical work. The Journal of Finance, v. 25, n.2, March, p.383-417, 1970.

Efficient Capital Markets - Portifolio Decisions and Securities Prices; New York: Basic Books, 1976.

$\overline{1617,1991 .}$

Efficient Capital Markets: II; The Journal of Finance, Vol. 46, No. 5, pp. 1575-

FÁVERO, L. P.; BELFIORE, P.; SILVA, F. L.; CHAN, B. L. Análise de dados: modelagem multivariada para tomada de decisões. Rio de Janeiro: Elsevier, 2009.

GITMAN, L. J.; Principles of Managerial Finance; EUA, 10th ed.; Addison Wesley, 2002.

HENDRIKSEN, E. S.; VAN BREDA, M. F. Teoria da Contabilidade. Tradução da $5^{\circ}$ ed. Americana, por Antonio Zoratto Sanvicente. São Paulo: Atlas, 2009.

IUDÍCIBUS, S.; LOPES, A. B.; Teoria Avança da Contabilidade; São Paulo: Atlas, 2004.

JAFFE, J. F.; Special Information and Insider Trading; The Journal of Business, Vol. 47, No. 3, pp. 410-428; Julho, 1974. 
KAHANEMAN, D.; Maps of bounded rationality: psychology for behavioral economics. The American Economic Review. p. 1449-1473; Dezembro, 2003.

KAYO, Eduardo Kazuo. A Estrutura de Capital e o Risco das Empresas Tangível e Intangível-Intensivas: Uma Contribuição ao Estudo da Valoração de Empresas. Tese (Doutorado em Administração) - Faculdade de Economia, Administração e Contabilidade da Universidade de São Paulo. São Paulo, 2002.

KELOHARJU, M. The Winner's Curse, Legal Liability, and the Long-Run Price Performance of Initial Public Offerings in Finland. Journal of Financial Economics 34, p. 251-277, 1993.

KOH, F., WALTER, T.; A direct test of Rock's model of the pricing of unseasoned issues. Journal of Financial Economics N.23, 251-272, 1989.

KORAJCZYK, R. A; LUCAS, D. J; MCDONALD, R. L; The Effect of Information Releases on the Pricing and Timing of Equity Issues; The Review of Financial Studies (1986-1998) vol 4 ed. 4, 1991.

LIMA, G.A.S.F.; Governança Corporativa e Hipótese de Mercados Eficientes: O Estudo do Anúncio da Emissão de American Depositary Receipts (ADRs) com Utilização de Estudo de Evento; Dissertação de Mestrado; Faculdade Economia, Administração e Ciências Contábeis; Universidade de São Paulo. São Paulo, 2005.

LIMA, I.S.; LIMA, G.A.S.F.; PIMENTEL, R.C.; Curso de Mercado Financeiro - Tópicos Especiais; São Paulo: Atlas, 2009.

LJUNGQVist, A.; BOEHMER, E. On the Decision to Go Public: Evidency from Privately-Held Firms. Working paper, New York University, 2004.

LOPES, A. B.; MARTINS, E.; “Teoria da Contabilidade: Uma Nova Abordagem” São Paulo: Atlas, 2007.

LOPES, A. B.; GALDI, F. C.; Financial Statement Analysis also Separete Winners from Loser. São Paulo: FGV, 2006.

Does financial statement analysis generate abnormal returns under extremely adverse conditions? In: Annual Meeting of the American Accounting Association. Chicago, Illinois. 2007.

LOUGHRAN, T.; RITTER, J. R.; Why Don't Issuers Get Upset About Leaving Money on the Table in IPOs? The Review of Finantial Studies, 2002. 413-443. 
MACKINLAY, C.; Event Studies in Economics and Finance. Journal of Economic Literature. Vol. 35, p. 13-39. Março, 1997.

MAKSIMOVIC, V.; PICHLER P.; "Technological innovation and initial public offerings", Review of Financial Studies 14, 459-494, 2001.

MARKOWITZ, H.; Portfolio Selection; The Journal of Finance, Vol. 7, No. 1, pp. 77-91, 1952.

MAYO, H. B.; "Finanças Básicas"; Tradução da $9^{\circ}$ ed. norte-americana; São Paulo: Cengage Learning, 2008.

McGUIRE, J. B.; SUNDGREN, A.; SCHNEEWEIS, T.; Corporate social responsability and firm financial performance. Academy of Management Journal. Biarcliff Manor, v. 31, n. 4, p. 854-872, Dec. 1984.

MICHAELY, R., SHAW, W.; The pricing of initial public offerings: tests of adverseselection and signaling theories. Review of Financial Studies N. 7, 279-319, 1994.

MORRIS, R. D. S., Agency theory and accounting policy choice. Accounting and Business Research, v. 18, n. 69, p. 47-69, 1987.

MYERS, S. C., 1984, “The capital structure puzzle”, Journal of Finance 39, 575-592.

MYERS, S. C., MAJLUF , N. S., 1984, "Corporate financing and investment decisions when firms have information that investors do not have", Journal of Financial Economics 13, 187-221.

PANNEMANS, Sabine "Going Public: Opportunism or Necessity? Empirical Evidence From Belgian IPOs”. 2002; Eunip Conference 2002.

PETERS, E; Chaos and order in the Capital Markets, a new view of cycles, prices and Market volatility. Nova York; John Wiley \& Sons, Inc; 1991.

Fractal Market analysis: applying chãos theory to investment and economics. Nova York; John Wiley \& Sons, Inc; 1994.

PIMENTEL, L. A. S. Fluxos de Capitais Externos, Crescimento e Desenvolvimento Econômico: Evidências de Causalidade. Dissertação de Mestrado. FEA USP, Ribeirão Preto, 2007.

PIOTROSKI, J. D.; Value investing: The use of historical financial statement information to separate winners from losers. Journal of Accounting Research, V. 38, pp. 1-41, 2000. 
RITTER, J. R.; The Long-Run Performance of Initial Public Offerings; Journal of Finance; 46, 3-27; 1991.

RITTER, J. R.; WELCH, I. A Review of IPO Activity, Pricing and Allocations. The Journal of Finance, p. 1795-1828, 2002.

ROBERTS, Harry V.; Stock Market "Patterns" and Financial Analysis: Methodological Suggestions. Journal of Finance, n. 44, p. 1-10, 1959.

- Statistical versus Clinical Prediction in the Stock Market, manuscrito não publicado, Center for Research in Security Prices, University of Chicago.

ROCK, K.; Why new issues are underpriced, Journal of Financial Economics N.15, 187212. 1986.

RODRIGUES, A.; PAULO, E.; CARVALHO, L. N. Gerenciamento de resultados por meio das transações entre companhias brasileiras interligadas. Revista de Administração - USP. V. 42, n. 2. p. 216-226. 2007.

ROSS, S. A.; The Arbitrage Theory of Capital Asset Pricing; Journal of Economic Theory; Vol. 13 Issue 3, p341-360, 20p, 1976.

ROSS, S. A.; WESTERFIELD, R. W.; JAFFE, J. F. Corporate Finance; 8 ed. New York: McGraw-Hill, 2008.

SAITO, R.; MACIEL L. P. Underpricing of Brazilian IPOs: Empirical Evidence from 1999 to 2005. In:Econtro Annual da Associação Nacional de Pós-Graduação e Pesquisa em Administração, 2006, Salvador. Anais Eletrônicos, Salvador, ANPAD 2006.

SANTOS, T. B. DE S.; Desenvolvimento financeiro e crescimento econômico: A modernização do Sistema Financeiro Brasileiro. São Paulo, 2005. Teses de doutorado Faculdade de Filosofia, Letras e Ciências Humanas, Universidade de São Paulo.

SHARPE, W. F.; Capital Asset Prices - A Theory of Market Equilibrium Under Conditions of Risk; Journal of Finance, Vol. 19, No. 3, pp 425-442, 1964.

SPENCE, M.; Job Market signaling. Guarterly Journal of Economics, 87. 355-74, 1973.

SPENCE, M.; Market signaling, Harvard University press, Cambridge, USA, 1974.

VARIAN, H. R.; Microeconomia Princípios Básicos; 7 ed. Rio de Janeiro: Elsevier Editora, 2006. 
WATTS, R. L.; ZIMMERMAN, J. L.; Positive Accounting Theory. Englewood Cliffs: Prentice Hall, 1986.

WOOLDRIDGE, J. M.; Introdução à Econometria: Uma Abordagem Moderna; 4 ed. Traduzida, São Paulo: Cengage Learning, 2010.

ZINGALES, L.; Insider Ownership and the Decision to Go Public. The Review of Economic Studies, Vol. 62, No. 3 (jul., 1995), pp. 425-448, 1995. 


\section{APÊNDICE 1}

\begin{tabular}{|c|c|c|c|c|c|}
\hline \multicolumn{6}{|c|}{ Ofertas Públicas realizadas entre Janeiro de 2007 e Dezembro de 2011. Fonte BM\&FBovespa } \\
\hline EMPRESAS & OFERTAS & EMPRESAS & OFERTAS & EMPRESAS & OFERTAS \\
\hline BR MALLS & 4 & Bic Banco & 1 & Magnesita & 1 \\
\hline PDG Realty & 4 & $\mathrm{BM} \& \mathrm{~F}$ & 1 & Mahle & 1 \\
\hline Anhanguera Educ. & 3 & Bovespa Holding & 1 & Marisa & 1 \\
\hline Hypermarcas & 3 & BR Pharma & 1 & Metal. Gerdau & 1 \\
\hline Redecard & 3 & Brasil Insurance & 1 & Metalfrio & 1 \\
\hline Banco Brasil & 2 & Brookfield & 1 & MILLS & 1 \\
\hline BR Properties & 2 & Camargo Correia & 1 & Minerva SA & 1 \\
\hline Brasil Brokers & 2 & $\mathrm{CCR}$ & 1 & MPX Energia & 1 \\
\hline Direcional & 2 & Cetip & 1 & Multiplus & 1 \\
\hline Even SA & 2 & Cia Hering & 1 & Natura & 1 \\
\hline Gafisa & 2 & Copasa & 1 & OGX Petróleo & 1 \\
\hline Gerdau & 2 & Cosan Limited BDR & 1 & OSX BRASIL & 1 \\
\hline Iguatemi & 2 & CR2 Empreend. Imob. & 1 & Paraná Banco & 1 \\
\hline Inpar & 2 & Cremer & 1 & Providencia & 1 \\
\hline JBS & 2 & Cyrella & 1 & Qgep Part & 1 \\
\hline Kroton Educ. & 2 & Drogasil & 1 & Qualicorp & 1 \\
\hline Marfrig & 2 & Ecorodovias & 1 & Raia & 1 \\
\hline MRV Engenharia & 2 & EDP & 1 & Renova & 1 \\
\hline Multiplan & 2 & Embraer & 1 & Rodobens & 1 \\
\hline Perdigao & 2 & Energias do Brasil & 1 & Romi & 1 \\
\hline Petrobras & 2 & Estacio & 1 & Rossi Resid & 1 \\
\hline SLC Agricola & 2 & Estacio Part. & 1 & Santander & 1 \\
\hline Tecnisa & 2 & EZ Tec Empreend. & 1 & Sao Martinho & 1 \\
\hline ABC Brasil & 1 & Fertilizantes Heringer & 1 & Satipel & 1 \\
\hline Abril Educação & 1 & Fleury & 1 & SEB & 1 \\
\hline Acucar Guarani & 1 & General Shopping & 1 & SierraBrasil & 1 \\
\hline Agra & 1 & GOL & 1 & Springs & 1 \\
\hline Agrenco & 1 & GP Investments & 1 & Sul América & 1 \\
\hline Aliansce & 1 & GVT SA & 1 & Suzano Papel & 1 \\
\hline Amil & 1 & Helbor & 1 & Technos & 1 \\
\hline Anhanguera & 1 & HRT Participações & 1 & Tegma Gestao Log. & 1 \\
\hline Arezzo & 1 & IMC Hold.(Int Meal) & 1 & Tempo Part. & 1 \\
\hline Autometal & 1 & Invest Tur & 1 & Tenda & 1 \\
\hline Banco Indusval & 1 & JHSF Participaçöes & 1 & TIM & 1 \\
\hline Bco Panamericano & 1 & Julio Simões & 1 & Time For Fun & 1 \\
\hline Banco Pine & 1 & Laep & 1 & Tivit & 1 \\
\hline Banco Sofisa & 1 & Le Lis Blanc & 1 & Trisul & 1 \\
\hline Banrisul & 1 & Light & 1 & Triunfo Part. Invest & 1 \\
\hline Bco Cruzeiro Sul & 1 & Log-In Logistica & 1 & Usiminas & 1 \\
\hline Bco Daycoval & 1 & LPS Brasil & 1 & Vale & 1 \\
\hline Bematech & 1 & Magazine Luiza & 1 & Visanet / Cielo & 1 \\
\hline
\end{tabular}


APÊNDICE 2

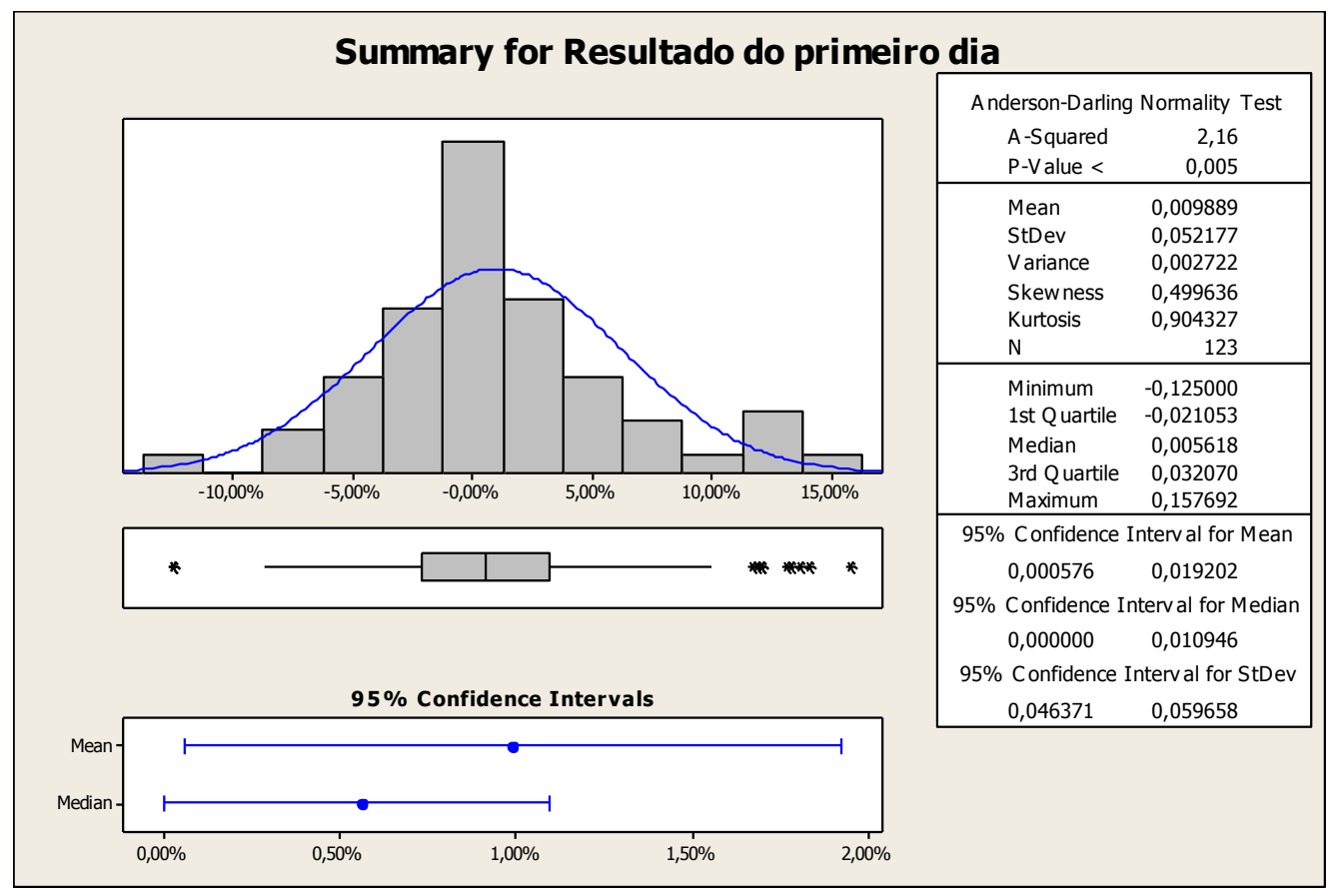




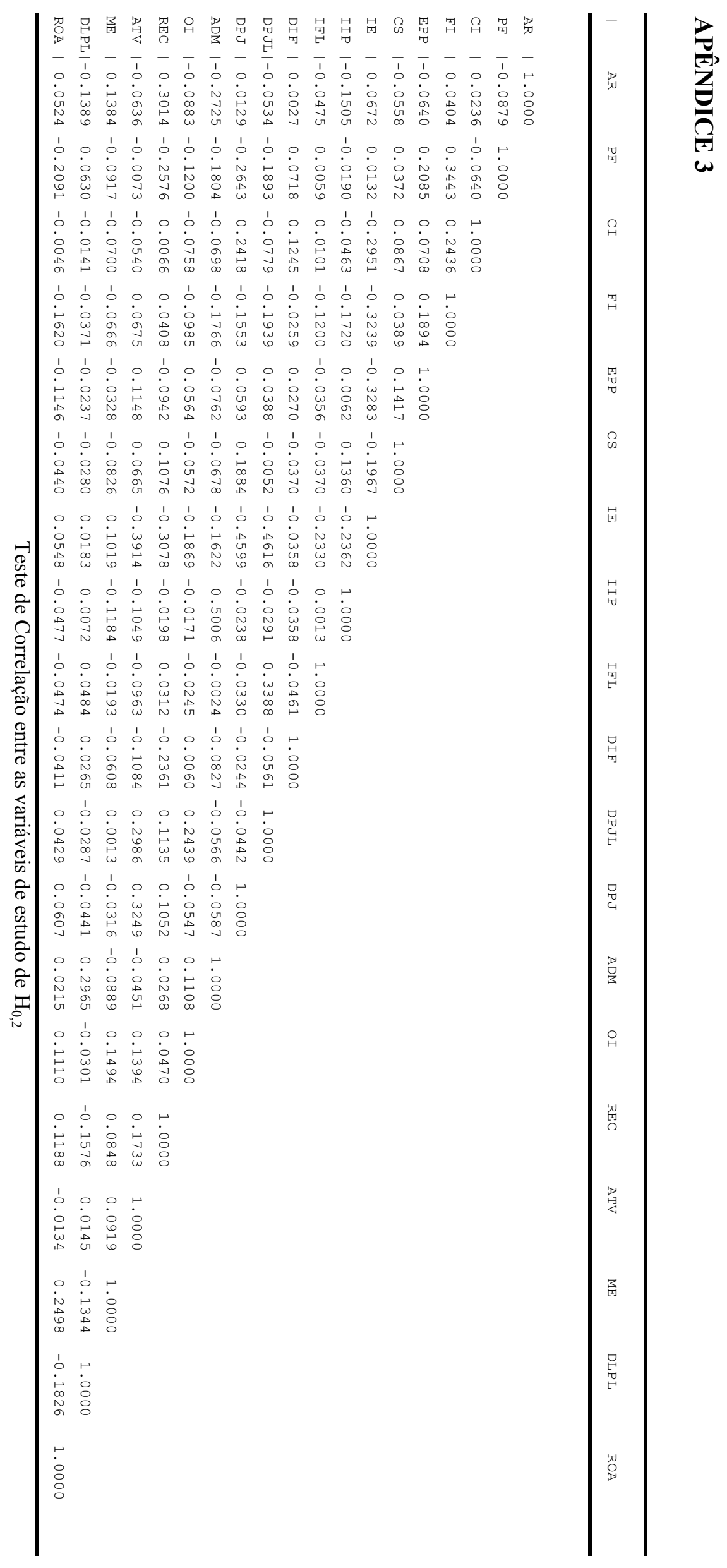

